\title{
Transbilayer phospholipids molecular imaging
}

\author{
Tarik Z Belhocine ${ }^{1 *}$ and Frank S Prato ${ }^{1,2}$
}

\begin{abstract}
Nuclear medicine has become a key part of molecular imaging. In the present review article, we focus on the transbilayer phospholipids as exquisite targets for radiolabelled probes in molecular imaging. Asymmetry of phospholipid distribution is a characteristic of mammalian cell membranes. Phosphatidylcholine and sphyngomyelin cholinophospholipids are primarily located within the external leaflet of the cell membrane. Phosphatidylserine and phosphatidylethanolamine aminophospholipids, and also phosphatidylinositol are primarily located within the internal leaflet of the cell membrane. New radiolabelled tracers have been designed in preclinical and clinical research for PET-CT and SPECT-CT molecular imaging of transbilayer phospholipids.
\end{abstract}

Keywords: phospholipids, molecular imaging, PET-CT, SPECT-CT

\section{Introduction}

In this beginning of the twenty-first century, personalized molecular medicine is the objective of molecular diagnosis, molecular imaging, and molecular therapy $[1,2]$. Molecular imaging (MI) includes a number of morphological imaging techniques (i.e. ultrasound, computed tomography and magnetic resonance imaging), and optical imaging techniques (i.e. bioluminescence and fluorescence imaging) $[3,4]$. In addition, nuclear medicine with radiolabelled probes has become a key part of MI, especially with ${ }^{18}$ F-fluorodeoxyglucose $\left({ }^{18} \mathrm{~F}\right.$-FDG) metabolic imaging [5]. New radiolabelled tracers have been designed for positron emission tomography-computed tomography (PET-CT) and single-photon emission computed tomography-computed tomography (SPECT-CT) molecular imaging [6]. In this review article, we focus on the transbilayer phospholipids as exquisite targets for radiolabelled probes in molecular imaging.

\section{Molecular imaging}

There is no universally accepted definition of molecular imaging [5,7]. In 2000, the Society of Molecular Imaging http://www.molecularimaging.org/ defined molecular imaging as: 'the characterization and measurement of biological processes in living animals at the cellular and molecular level'. In 2005, the European Society for Molecular Imaging http://www.e-smi.eu formulated a

\footnotetext{
* Correspondence: tbelhocine@yahoo.ca

'Department of Medical Imaging, The University of Western Ontario,

London, ON, Canada

Full list of author information is available at the end of the article
}

definition of molecular imaging as: 'the characterisation of the dynamics of the molecular processes in the living organisms in vivo. In vivo molecular imaging is a science combining molecular biology, cellular biology and physiology with imaging in living subjects'. In 2006, the Federation of Asian Societies for Molecular Imaging (FASMI: http://fasmi.org/) defined molecular imaging as: 'the characterization and measurement of biological processes in living animals at the cellular and molecular level by means of non-invasive (or minimally invasive) imaging'. In 2007, the Society of Nuclear Medicine Molecular Imaging Center of Excellence http://interactive. snm.org/ definitions task force approved this definition of molecular imaging as: 'the visualization, characterization, and measurement of biological processes at the molecular and cellular levels in humans and other living systems' [8]. A MI probe is a molecule used in molecular imaging to deliver a tracer to a specific organ or tissue. A probe typically consists of a ligand containing or linked to a signalling label. The label provides the signal (i.e. electromagnetic wave, light and radiation) that can be picked up by a detector, and the ligand carries the tracer to the site of interest [9]. A MI target used in molecular imaging is a molecule or structure in the body to which binds a probe delivered to a specific organ or tissue. The target may be a peptide, or a glucide, or a lipid; in many cases, the target is a protein $[10,11]$. Molecular imaging may be a single disease/gene or a general disease/biologic function control point for targeting [12].

Molecular imaging with transbilayer phospholipid targets may be performed with radiolabelled probes such (c) 2011 Belhocine and Prato; licensee Springer. This is an Open Access article distributed under the terms of the Creative Commons Attribution License (http://creativecommons.org/licenses/by/2.0), which permits unrestricted use, distribution, and reproduction in any medium, provided the original work is properly cited. 
as radiolabelled annexin $\mathrm{V}$ or $\mathrm{C} 2 \mathrm{~A}$ synaptotagmin domain I or beta 2 glycoprotein I, radiolabelled duramycin, radiolabelled hypericin, radiolabelled lactadherin, radiolabelled choline or fluorocholine, radiolabelled diacylglycerols, radiolabelled sphyngomyelin for visualization, characterization and measurement of key biological functions (i.e. apoptosis, necrosis, thrombosis, vasculature endothelium, choline metabolism, myocardial and neuronal phosphoinositide turnover) or for assessing specific diseases (i.e. cancers, immune diseases, inflammatory diseases, infectious diseases, cardiac diseases and neurological diseases).

\section{Membrane bilayer}

The membrane bilayer is composed of $40 \%$ lipids and glycolipids, and $60 \%$ integral proteins and glycoproteins [13]. The lipids in the membrane bilayer are composed of phospholipids ( $75 \%$ to $88 \%$ ), glycosphyngolipids ( $2 \%$ to $5 \%$ ) and cholesterol (10\% to $20 \%$ ) [13]. The phospholipids include phosphatidylcholine ( $45 \%$ to $55 \%$ ), phosphatidylethanolamine (15\% to $25 \%$ ), phosphatidylinositol (10\% to $15 \%)$, phosphatidylserine ( $2 \%$ to $10 \%$ ), phosphatidic acid (1\% to $2 \%)$, sphyngomyelin (5\% to $10 \%)$ and cardiolipin (2\% to $5 \%$ ). Liposomes are artificial lipid vesicles encapsulating drugs (e.g. chemotherapy drugs, antibiotics, fungicides), enzymes, biological material (e.g. antigens, antibodies) and tracers (e.g. radiolabelled products, contrast agents) [14]. Liposomes are nanoparticles with a diameter $<100 \mathrm{~nm}$ characterised by the composition of lipids, the number of membrane bilayers, and the surface charges [7]. The material encapsulated is either dissolved in an aqueous phase or in a lipid phase. Radioactive phospholipid liposomes have been designed for molecular imaging [15].

\section{Phospholipid bilayer}

In 1972, Singer and Nicolson developed the fluid mosaic model to explain the composition of the cell membrane bilayer with randomly oriented globular proteins and lipids [16]. According to this thermodynamic model, the phospholipid membrane bilayer is composed of hydrophilic heads and hydrophobic tails. The polar hydrophilic heads are in contact with water (see Figure 1). Recent refinements of the Singer-Nicolson mosaic model suggest a structured dynamic organisation of the membrane bilayer with genetically predefined non-randomly oriented globular proteins into the lipid matrix $[17,18]$. In mammalians, the asymmetry of phospholipid distribution is a characteristic of cell membranes (see Figure 2). Phosphatidylcholine (PC) and sphyngomyelin (SM) cholinophospholipids are primarily located in the extracellular membrane. Phosphatidylethanolamine (PE) and phosphatidylserine (PS) aminophospholipids as well as phosphatidylinositol (PI) phospholipid are primarily located in the intracellular membrane [19]. Two ATP-dependent translocase enzymes (i.e. cholinophospholipid-specific translocase or floppase, and aminophospholipid-specific translocase or flippase) and a $\mathrm{Mg}^{2+}$-ATPase (i.e. aminophospholipid translocase) maintain the aminophospholipids in the inner leaflet of the membrane bilayer. PE and PS are externalised to the outer leaflet of the cell membrane after inactivation of aminophospholipid translocase or flippase and activation of scramblase, another $\mathrm{Ca}^{2+}$. dependent ATP-independent enzyme [19,20].

\section{Phospholipid targets}

Phospholipids are composed of a phosphatidyl tail including a free fatty acid, glycerol and phosphate [21]. In the phospholipid polar head, choline, serine, ethanolamine and inositol bind to the phosphatidyl non-polar tail. Sphingomyelin is the only one cell membrane phospholipid not derived from a glycerol but from an aminoalcohol sphingosine; SM is composed of a core ceramide (i.e. sphingosine and free fatty acid tail) and contains a polar head group composed of phosphocholine or phosphoethanolamine [22].

In preclinical and clinical research, phospholipids are used as targets for molecular imaging with radiolabelled probes as illustrated in Figure $3[23,24]$.

\section{PS target}

PS is an aminophospholipid located in the inner leaflet of the cell membrane. In pathophysiological conditions including apoptosis, thrombosis and tumour vasculature, PS is externalised from the inner leaflet to the outer leaflet of the cell membrane [25]. In necrosis, PS is exposed in the inner leaflet of damaged cells. For SPECT-CT and PET-CT imaging, radiolabelled probes have been designed to target exposed PS with or without the breakdown of cell membrane asymmetry.

Annexin $V$, a $36-\mathrm{kDa}$ serum protein first isolated from human placenta, has been radiolabelled with ${ }^{99 \mathrm{~m}} \mathrm{Tc},{ }^{111} \mathrm{In}$, ${ }^{67} \mathrm{Ga},{ }^{123} \mathrm{I},{ }^{124} \mathrm{I},{ }^{11} \mathrm{C},{ }^{64} \mathrm{Cu},{ }^{68} \mathrm{Ga},{ }^{94 \mathrm{~m}} \mathrm{Tc}$ and ${ }^{18} \mathrm{~F}$ for imaging of apoptosis or necrosis, and thrombosis [26-29]. Annexin $\mathrm{V}$ binds specifically to PS in presence of $\mathrm{Ca}^{2+}$ ions. Spontaneous and induced apoptotic changes may be assessed qualitatively and quantitatively with radiolabelled annexin V-targeted to PS [30,31]. In preclinical research, ${ }^{99 \mathrm{~m}} \mathrm{Tc}$ HYNIC-annexin V imaging has been used to evaluate cardiovascular models (e.g. heart transplant rejection, myocarditis and mural thrombus), oncology models (e.g. cyclophosphamide induced intramedullary and splenic apoptosis in lymphoma), neurology models (e.g. neonatal brain ischemia), inflammatory/infectious models (e.g. fulminant hepatitis, subacute and acute infection) and immune models (e.g. rheumatoid arthritis treated by corticosteroids). In clinical research, ${ }^{99 \mathrm{~m}} \mathrm{Tc}$-HYNIC-annexin $\mathrm{V}$ imaging using a recombinant human form of annexin $\mathrm{V}$ 


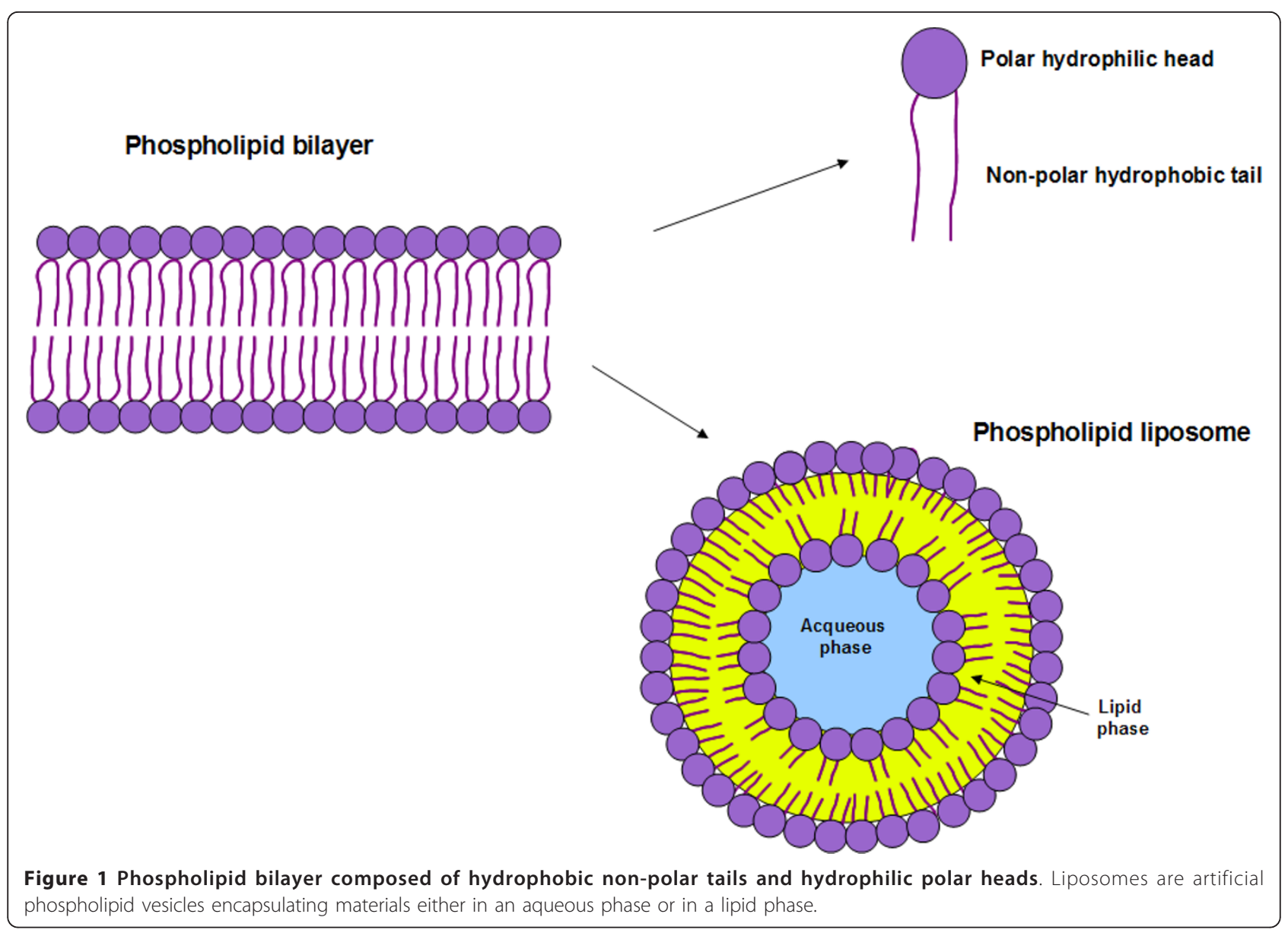

has been used to assess myocardial infarction, heart transplant rejection, atherosclerosis, ischemic pre-conditioning and chemotherapy/radiation therapy-induced apoptosis in head and neck cancers, lymphomas, lung cancers, breast cancers, leukaemia and soft tissue sarcomas. ${ }^{99 \mathrm{~m}} \mathrm{Tc}$ HYNIC-annexin V imaging has also been used in patients with dementia and stroke, and in patients with rheumatoid arthritis and Crohn's disease for evaluation of early apoptotic response to Infliximab ${ }^{\circledR}$ therapy (i.e. anti-TNF $\alpha$ monoclonal antibody) $[24,26]$. Figures 4 and 5 illustrate PS targeting ${ }^{99 \mathrm{~m}} \mathrm{Tc}$-HYNIC-annexin $\mathrm{V}$ molecular imaging probe in a patient with a non-small cell lung cancer (NSCLC). PS targeting ${ }^{99 \mathrm{~m}}$ Tc-annexin V-128 with an Nterminal site specific for endogenous binding of technetium-99m has been designed in order to improve the sensitivity of detection of apoptosis or necrosis (i.e. twofold higher than that of ${ }^{99 \mathrm{~m}}$ Tc-HYNIC-annexin V) [32].

$>$ C2A domain of synaptotagmin $I(\mathrm{C} 2 \mathrm{~A})$ is a $12-\mathrm{kDa}$ protein predominantly located within the synaptic vesicles binding to PS. It has been fused with glutathione-stransferase (GST) and radiolabelled with ${ }^{99 \mathrm{~m}} \mathrm{Tc}$ for imaging of apoptosis or necrosis [33]. In a rat and pig model of acute myocardial infarction, increased ${ }^{99 \mathrm{~m}} \mathrm{Tc}$ -
C2A-GST uptake was seen in the myocardial infarct area at risk, and was associated with wall dysfunction [34-36]. In a mouse model of NSCLC, increased ${ }^{99 \mathrm{~m}} \mathrm{Tc}$ C2A-GST tumour uptake was noted after paclitaxel chemotherapy-induced apoptosis [37]. Also, C2A-GST has been easily labelled with ${ }^{18} \mathrm{~F}$ for early imaging of apoptosis after chemotherapy [38]. In a rabbit model of lung cancer, increased ${ }^{18} \mathrm{~F}-\mathrm{C} 2 \mathrm{~A}-\mathrm{GST}$ tumour uptake was detected $72 \mathrm{~h}$ after paclitaxel chemotherapy with increased apoptotic index and caspase- 3 activity. Recently, the C2A domain of synaptotagmin I has been labelled with a $\left[{ }^{99 \mathrm{~m}} \mathrm{Tc}(\mathrm{CO})_{3}{ }^{+}\right]$core by using an efficient $\mathrm{C}$-terminal site-specific radiolabelling method for the imaging of cell death [39].

PS is not exposed in normal endothelium, but increased exposure of PS is seen on the tumour endothelium vasculature $[40,41]$. Bavituximab, a chimeric monoclonal antibody $(\mathrm{MW}=145.3 \mathrm{kDa})$ binding to the beta-2 glycoprotein I domain of PS, has been radiolabelled with the $\beta+$ emitter arsenicum-74 $\left({ }^{74} \mathrm{As}\right.$, $T_{1 / 2}=17.8$ days) for tumour vasculature PET imaging, and with the $\beta-, \gamma$ emitter ${ }^{77}$ As $\left(T_{1 / 2}=38.8 \mathrm{~h}\right)$ for SPECT imaging and potential tumour vasculature 


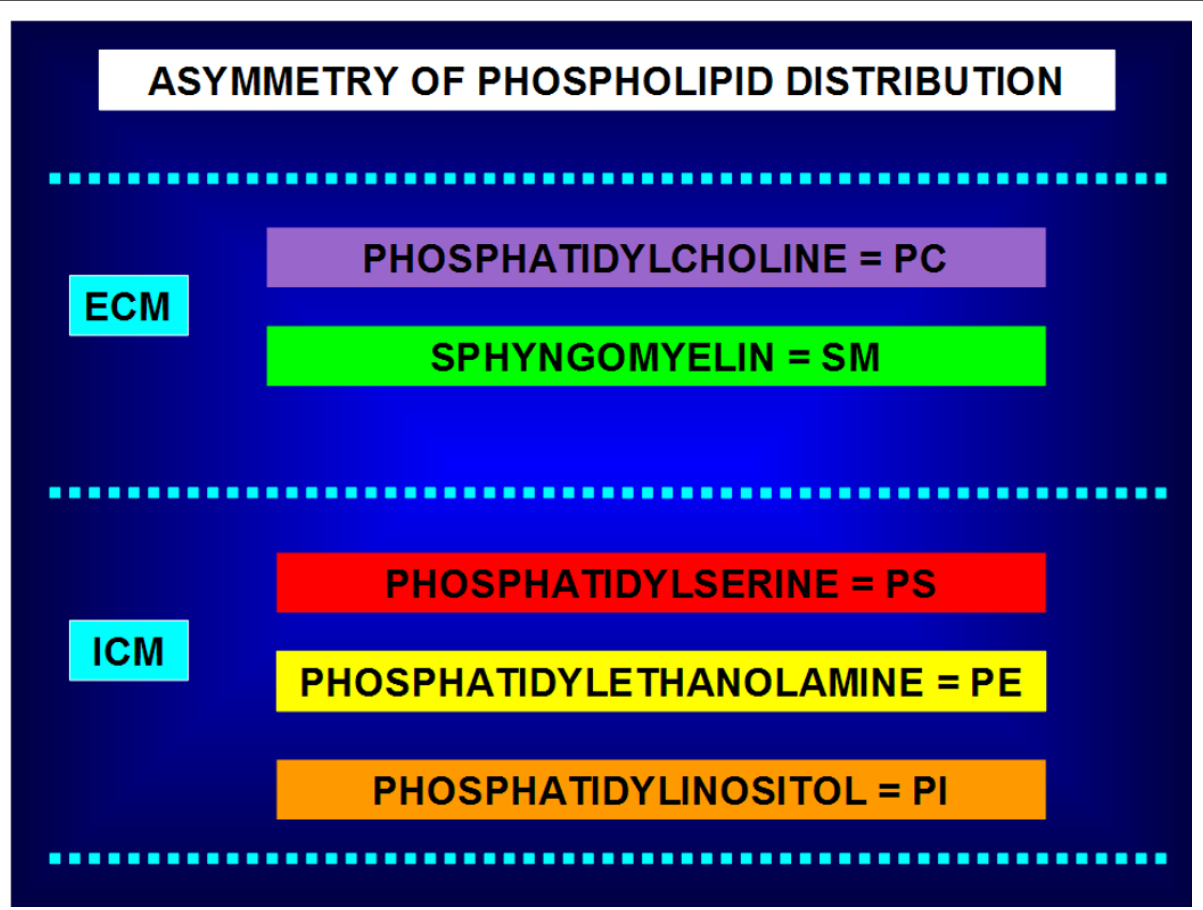

Figure 2 Asymmetry of phospholipid distribution. Phosphatidylcholine (PC) and sphyngomyelin (SM) cholinophospholipids are primarily located in the external leaflet of the cell membrane (ECM). Phosphatidylserine (PS) and phosphatidylethanolamine (PE) aminophospholipids as well as phosphatidylinositol (PI) phospholipid are primarily located in the internal leaflet of the cell membrane (ICM). In mammalians, the asymmetry of phospholipid distribution is maintained by the flip/flop movement of phospholipids. PS and PE are maintained to the inner leaflet of the membrane bilayer by the $\mathrm{Mg}^{2+}$-ATPase (i.e. aminophospholipid translocase), and the ATP-dependent aminophospholipid-specific flippase and cholinophospholipid-specific floppase (i.e. multidrug resistance proteins). In pathophysiological conditions, PS and PE are shuttled to the outer leaflet after inactivation of the aminophospholipid translocase or flippase, and activation of the $\mathrm{Ca}^{2+}$-dependent ATP-independent scramblase.

endothelium therapy [42-44]. Increased ${ }^{74}$ As-bavituximab uptake was seen in a rat model of prostate cancer with the highest tumour-to-background activity ratio at $72 \mathrm{~h}$ post-i.v injection (at $72 \mathrm{~h}$ p.i., tumour-to-liver ratio $=22$, and tumour-to-muscle ratio $=470)$. Using autoradiography and immunohistochemical studies, ${ }^{74}$ As-bavituximab was found to specifically bind to the tumour endothelium vasculature. Bavituximab radiolabelled with ${ }^{77}$ As or ${ }^{76} \mathrm{As}\left(\beta-, T_{1 / 2}=26.3 \mathrm{~h}\right)$ may be used for dosimetry and immunotherapy.

Hypericin, a non-porphyrin necrosis agent (MW $=504$ $\mathrm{Da})$ extracted from St John's wort, has been labelled with ${ }^{64} \mathrm{Cu}\left(\beta+, T_{1 / 2}=12.7 \mathrm{~h}\right)$ for PET imaging of necrosis. In a female mouse model of BT474 breast xenograft tumour, ${ }^{64} \mathrm{Cu}$-bis-DOTA-hypericin demonstrated increased uptake at $24 \mathrm{~h}$ post-i.v. injection in necrotic injured tissues treated with near infrared photothermal ablation therapy. PET distribution also showed higher uptake in the liver and the kidneys. Bis-DOTA-hypericin had a selective binding affinity for PS and PE phospholipids [45]. In necrosis, PS and $\mathrm{PE}$ are exposed to ${ }^{64} \mathrm{Cu}$-labelled hypericin probe in the inner leaflet of damaged cell membrane. Hypericin derivatives are efficient and yield reproducible results when radiolabelled with ${ }^{123} \mathrm{I}$ (i.e. mono- ${ }^{123}$ I-iodohypericin and mono- ${ }^{123}$ I-iodohypericin monocarboxylic acid). They have been also used in preclinical models of liver necrosis and myocardial infarction as well as in clinical correlates of these pathophysiologic states $[46,47]$. In a preclinical rat model of liver rhabdomyosarcoma, ${ }^{131}$ I-labelled hypericin was successfully used in theragnostics with a vascular disrupting agent (i.e. combretastatin A4 phosphate or CA4P); high radiolabelling efficiency was noted with minimum deiodination. ${ }^{131}$ I-hypericin uptake colocalised tumour necrosis within $24 \mathrm{~h}$ post-i.v. injection on co-registered planar $\gamma$ scintigraphy with CT, MRI, histology and autoradiography [48]. Hypericin has also been labelled with ${ }^{99} \mathrm{~m}$ Tc (i.e. ${ }^{99 \mathrm{~m}} \mathrm{Tc}$-hypericin or ${ }^{99 \mathrm{~m}} \mathrm{Tc}$-mercaptoacetyldiglycyl-1,5-diaminopentylene hypericin-carboxamide) for visualisation of necrotic tissues in rats with reperfused liver infarct [49]. ${ }^{99 \mathrm{~m}} \mathrm{Tc}$-hypericin, however, was found to be not suitable for imaging of necrosis compared to ${ }^{123} \mathrm{I}$ hypericin derivatives [50]. Although the mechanism of target uptake is unknown, it may be hypothesised that the PS and PE phospholipid targets are involved for ${ }^{123} \mathrm{I}-,{ }^{131} \mathrm{I}-$ and ${ }^{99 \mathrm{~m}} \mathrm{Tc}$-labelled hypericin derivatives, but this is still to be definitely proven. 


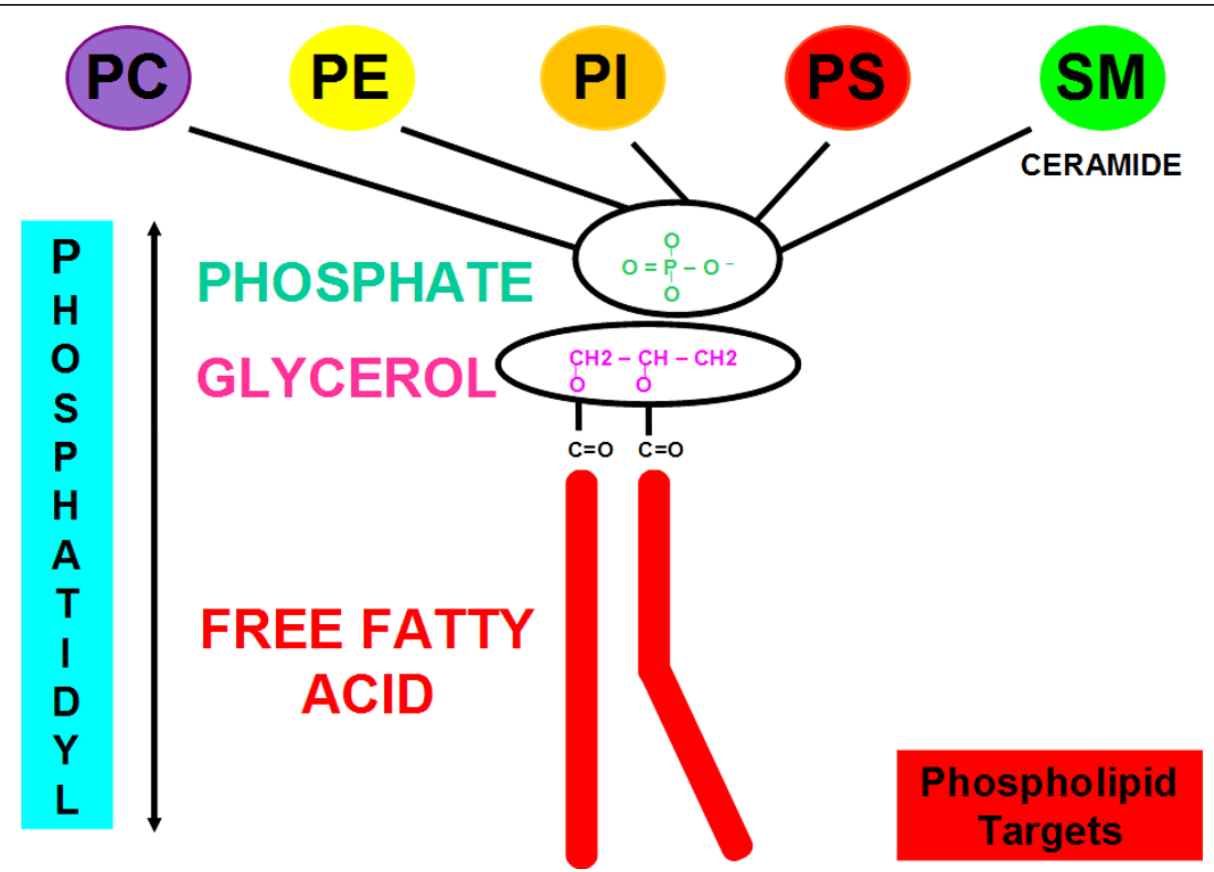

Figure 3 Phospholipid targets are composed of a phosphatidyl tail including free fatty acid, glycerol, and phosphate. In the phospholipid polar head, choline, serine, ethanolamine, and inositol bind to the phosphatidyl non-polar tail. Sphingomyelin is the only one cell membrane phospholipid not derived from a glycerol but from an aminoalcohol sphingosine; SM is composed of a core ceramide (i.e. sphingosine and free fatty acid tail) and contains a polar head group composed of phosphocholine or phosphoethanolamine.

Lactadherin, a glycoprotein secreted by mammary epithelium, epididymal epithelium, vascular cells and activated macrophages, has been shown to bind in a $\mathrm{Ca} 2+$-independent manner and specifically to the $\mathrm{C} 2$ domain of PS [51-53]. In vitro, FITC-labelled bovine lactadherin has been used for early detection of apoptosis in leukaemia cell lines treated by etoposide, and also in HeLa cervical cancer lines treated by staurosporine $[54,55]$. HYNIC-lactadherin has also been successfully labelled with ${ }^{99 \mathrm{~m}} \mathrm{Tc}$ (i.e. ${ }^{99 \mathrm{~m}} \mathrm{Tc}$-HYNIC-lactadherin). In vivo, in a mouse model, ${ }^{99 \mathrm{~m}} \mathrm{Tc}$-HYNIC-lactadherin had a lower uptake in the kidneys compared to ${ }^{99 \mathrm{~m}} \mathrm{Tc}$ HYNIC annexin V. However, this new PS-targeting probe had a higher uptake in the liver, which is a disadvantage for imaging of liver and myocardial apoptosis [56].

PSBP-6 or PS-binding peptide-6, a synthetic 14 amino acid sequence $(\mathrm{MW}=1.623 \mathrm{kDa}$; $\mathrm{Kd}=100 \mathrm{nM}$ ) where Gln is replaced by Ala screened through a peptide library, showed the highest relative binding affinity and stability; a single amino acid chelator (SAAC) was introduced at the N-terminus position of PSBP- 6 to form a stable complex with ${ }^{99 \mathrm{~m}} \mathrm{Tc}$ (i.e. SAAC- ${ }^{99 \mathrm{~m}} \mathrm{Tc}-\mathrm{PSBP}-6$ ), and to improve the labelling efficiency. Unlike annexin $\mathrm{V}$, SAAC-PSBP-6 binding to PS is $\mathrm{Ca}^{2+}$ independent [57]. In DLD1 human colon carcinoma cells pretreated with increased TRAIL doses and also in murine melanoma B16/F10 cells treated with poly(L-glutamic acid) paclitaxel (PG-TXL), SAAC- $\left({ }^{99 \mathrm{~m}} \mathrm{Tc}\right)-\mathrm{PSBP}-6$ showed selective binding to apoptotic cells in vitro; confirmation was obtained with TUNEL staining and autoradiography. In treated and untreated nude mice, biodistribution data showed increased SAAC- $\left({ }^{99 \mathrm{~m}} \mathrm{Tc}\right)$ PSBP-6 uptake in the liver and the kidney in vivo. Preclinical studies are required to assess the sensitivity and specificity of this new PS binding molecular imaging probe. Table 1 summarises radiolabelled PS-based molecular imaging probes.

\section{PC target}

Choline is a main component of biomembranes targeted by the choline kinase enzyme, and is phosphorylated to intracellular phosphocholine and extracellular phosphatidylcholine [58]. Choline has been labelled with ${ }^{11} \mathrm{C}$ (i.e. ${ }^{11} \mathrm{C}$-choline) and more recently with ${ }^{18} \mathrm{~F}$ (i.e. ${ }^{18} \mathrm{~F}$-fluorocholine) for PET-CT imaging $[59,60]$. With a longer physical half-life, ${ }^{18} \mathrm{~F}$-fluorocholine $\left({ }^{18} \mathrm{~F}-\mathrm{FCH} ;{ }^{18} \mathrm{~F}, T_{1 / 2}=\right.$ $109 \mathrm{~min})$ is more suitable than ${ }^{11} \mathrm{C}$-choline $\left({ }^{11} \mathrm{C}, T_{1 / 2}=\right.$ $20 \mathrm{~min}$ ) for PET-CT imaging. In human subjects, ${ }^{18} \mathrm{~F}$ FCH showed a fast blood pool clearance with a peak $\leq$ 5 min post-i.v. injection, a fast tissue uptake and a predominantly renal excretion. Additionally, ${ }^{18} \mathrm{~F}-\mathrm{FCH}$ biodistribution changes very slowly later than $10 \mathrm{~min}$ after i.v. injection [61]. 


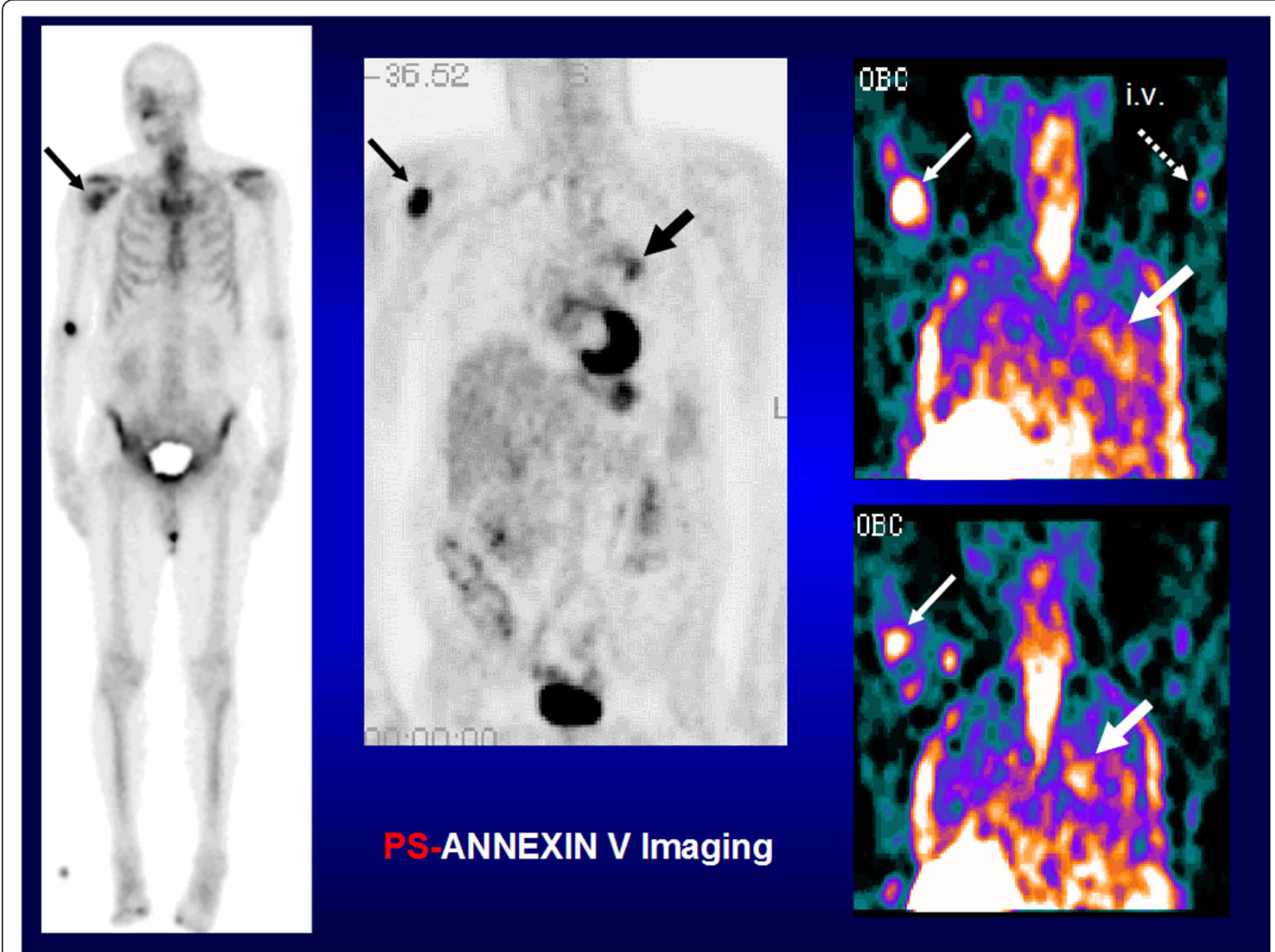

Figure 4 PS-annexin V imaging (North American Scientific 2020 - Phase II-III - Clinical Trial - Antwerp 2003). A patient with a left parahilar NSCLC (large black arrow) who presented with a bone metastasis in the right upper humerus (fine black arrow) on bone scan and ${ }^{18} \mathrm{FDG}$ PET. ${ }^{99 m} \mathrm{Tc}-\mathrm{HYNIC}$-annexin $\mathrm{V}$ imaging showed tracer uptake in the primary tumour (large white arrow) and the bone metastasis (fine white arrow) as soon as $24 \mathrm{~h}$ after the first course of chemotherapy. i.v., intravenous injection (dashed arrow).

${ }^{18} \mathrm{~F}$-fluorocholine $\left({ }^{18} \mathrm{~F}-\mathrm{FCH}\right)$ and ${ }^{11} \mathrm{C}$-choline are incorporated into the membrane phospholipids, and are predominantly used for prostate cancer imaging and brain tumour imaging $[62,63]$. In prostate cancer patients, ${ }^{18} \mathrm{~F}-\mathrm{FCH}$ is a promising tracer for detection of primary prostate cancer, staging of lymph node and bone metastases, and detection of recurrence after definitive therapy [62-64]. In brain tumours, this agent may be useful to detect glioblastoma multiforme, to distinguish high-grade gliomas with a characteristic peri-tumoural uptake from metastases and benign lesions, to guide a stereotactic biopsy, and also to differentiate post-radiation necrosis from recurrence [65-68]. Also, ${ }^{11} \mathrm{C}$-choline and ${ }^{18} \mathrm{~F}-\mathrm{FCH}$ have been used for hepatocellular carcinoma (HCC) imaging [69-71]. In a woodchuck model, ${ }^{11} \mathrm{C}$-choline sensitivity for detection of well-differentiated HCCs was higher than that of ${ }^{18} \mathrm{~F}-\mathrm{FDG}$, and in 12 patients with moderately differentiated $\mathrm{HCCs}$, the ${ }^{11} \mathrm{C}$ - choline detection rate was better than that of ${ }^{18} \mathrm{~F}$-FDG. ${ }^{18} \mathrm{~F}-\mathrm{FCH}$ imaging has also successfully been performed for detection of well-differentiated HCC in patients with liver nodules or cirrhosis or chronic liver disease, and for detection of recurrences from HCC $[72,73]$.

Under normal glucose conditions, acetate free fatty acid is metabolised into acetyl-CoA by acetyl-CoA synthetase in both the cytosol and mitochondria for synthesis of cholesterol and fatty acids [74]. In tumours, acetate is metabolised into fatty acids by fatty acid synthetase, which is overexpressed in cancer cells [75]. Acetate is mainly incorporated in the PC microdomains that play a major role for growth and metastasis [76]. Acetoacetate ketone body is metabolised to acetoacetyl$\mathrm{CoA}$ and to acetyl-CoA, and then incorporated into the metabolic pathway for lipid synthesis [77]. Like acetate, acetoacetate could be incorporated into the PC membrane. Acetate and acetoacetate have been labelled with 


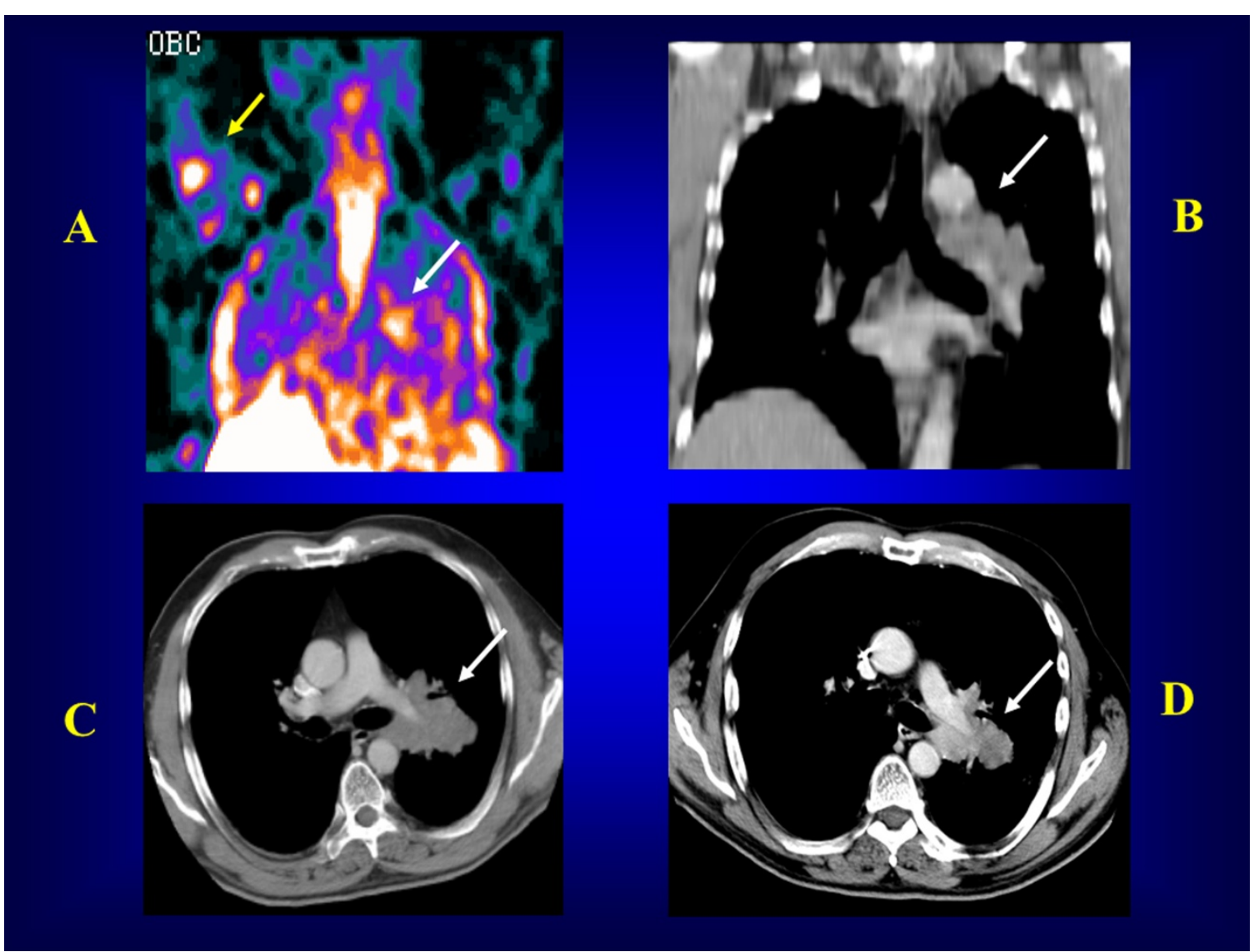

Figure 5 PS-annexin V imaging (North American Scientific 2020 - Phase II-III Clinical Trial - Antwerp 2003). A patient with a left para-hilar NSCLC on pre-chemotherapy CT (upper right: simple white arrow) who presented with ${ }^{99 \mathrm{~m}} \mathrm{Tc}$-HYNIC-annexin $V$ uptake post-chemotherapy in the primary lung tumour (upper left: simple white arrow) and the right upper humerus bone metastasis (upper left: yellow arrow). After the first course of chemotherapy, diagnostic CTs showed a decrease in the primary lung tumour greatest diameter, which was consistent with an apoptotic tumour response to chemotherapy (lower left and lower right: simple white arrows). Upper left (A): post-chemotherapy ${ }^{99 m} \mathrm{Tc}-\mathrm{HYNIC}$ annexin $\mathrm{V}$ scan; upper right (B) and lower left (C): pre-chemotherapy diagnostic CTs; lower right (D): post-chemotherapy diagnostic $C T$.

\section{Table 1 Phosphatidylserine-based radiolabelled molecular imaging probes}

\begin{tabular}{|c|c|c|c|c|c|c|c|}
\hline $\begin{array}{l}\text { Molecular } \\
\text { target }\end{array}$ & Molecular probes & AA & $\begin{array}{c}\mathrm{MW} \\
(\mathrm{kDa})\end{array}$ & $\begin{array}{l}\text { Affinity } \\
\text { (M) }\end{array}$ & Biological functions & Isotopes & $\begin{array}{l}\text { Imaging } \\
\text { techniques }\end{array}$ \\
\hline$\overline{\mathrm{PS}^{\mathrm{a}}}$ & annexin $\mathrm{V}$ & 319 & 36 & $10^{-9}$ & $\begin{array}{l}\text { apoptosis, necrosis, } \\
\text { thrombosis }\end{array}$ & $\begin{array}{l}{ }^{99 \mathrm{~m}} \mathrm{Tc},{ }^{123}{ }^{12},{ }^{111} \mathrm{In},{ }^{67} \mathrm{Ga},{ }^{18} \mathrm{~F},{ }^{68} \mathrm{Ga}, \\
{ }^{124},{ }^{64} \mathrm{Cu},{ }^{94 \mathrm{~m}} \mathrm{Tc}\end{array}$ & $\begin{array}{l}\text { SPECT(CT), PET } \\
(C T)\end{array}$ \\
\hline \multirow[t]{2}{*}{ PS } & $\begin{array}{l}\text { C2A domain of } \\
\text { synaptotagmin I }\end{array}$ & 128 & 12 & $10^{-9}$ & apoptosis, necrosis & ${ }^{99 \mathrm{~m}} \mathrm{Tc}$ & $\mathrm{SPECT}(\mathrm{CT})$ \\
\hline & & & & & & ${ }^{18} \mathrm{~F}$ & $\operatorname{PET}(C T)$ \\
\hline \multirow[t]{2}{*}{ PS ${ }^{b}$} & $\begin{array}{l}\text { bavituximab chimeric } \\
\text { antibody }\end{array}$ & - & 145.3 & $10^{-9}$ & $\begin{array}{l}\text { tumour endothelium } \\
\text { vasculature imaging }\end{array}$ & ${ }^{74} \mathrm{As}{ }^{\mathrm{c}}$ & $\operatorname{PET}(C T)$ \\
\hline & & & & & $\begin{array}{l}\text { tumour endothelium } \\
\text { vasculature therapy }\end{array}$ & ${ }^{77} \mathrm{As}^{\mathrm{d}}$ & SPECT(CT) \\
\hline PS & hypericin & - & 0.504 & - & necrosis & $\begin{array}{l}{ }^{99 \mathrm{~m}} \mathrm{Tc} \mathrm{c}_{,}{ }^{123} \mathrm{I}_{,}{ }^{131} \mathrm{l} \\
{ }^{64} \mathrm{Cu}{ }^{2}\end{array}$ & $\begin{array}{l}\text { SPECT(CT) } \\
\operatorname{PET}(C T)\end{array}$ \\
\hline PS & lactadherin & 364 & $47-50$ & $10^{-9}$ & apoptosis & ${ }^{99} \mathrm{~m} T \mathrm{C}^{\mathrm{f}}$ & $\operatorname{SPECT}(C T)$ \\
\hline PS & PSBP-6 & 14 & 1.623 & $10^{-9}$ & apoptosis, necrosis & ${ }^{99 m} \mathrm{Tc}_{\mathrm{c}}{ }^{\mathrm{g}}$ & $\mathrm{SPECT}(\mathrm{CT})$ \\
\hline
\end{tabular}

${ }^{a}$ Various linkers have been used for the radiolabelling of annexin $\mathrm{V}$ [26]. HYNIC is the most used bifunctional chelating agent in preclinical and clinical research. ${ }^{\mathrm{b}} \beta 2$ glycoprotein I domain of phosphatidylserine. ${ }^{\mathrm{c}}{ }^{74} \mathrm{As}, \beta+$ emitter $\left(T_{1 / 2}=17.8\right.$ days). ${ }^{\mathrm{d} 77} \mathrm{As}, \beta$ - emitter $\left(T_{1 / 2}=1.6\right.$ days). ${ }^{\mathrm{e}}$ Bis-DOTA has been used as a bifunctional chelating agent for radiolabelling of hypericin. ${ }^{\mathrm{f}} \mathrm{HYNIC}$ has been used as a bifunctional chelating agent for radiolabelling of lactadherin. ${ }^{\mathrm{g}}$ SAAC has been used as a single amino acid chelator for radiolabelling of PSBP-6. AA, amino acids; MW, molecular weight; PET(CT), positron emission tomography (computed tomography); PS, phosphatidylserine; PSBP-6, PS-binding peptide-6; SPECT(CT), single-photon emission computed tomography (computed tomography). 
${ }^{11} \mathrm{C}$ (i.e. ${ }^{11} \mathrm{C}$-acetate and ${ }^{11} \mathrm{C}$-acetoacetate) [74,77]. Acetate has also been labelled with ${ }^{18} \mathrm{~F}$ (i.e. ${ }^{18} \mathrm{~F}$-fluoroacetate) [78]. ${ }^{11} \mathrm{C}$-acetate has a rapid blood clearance with a high accumulation in liver and myocardium. In normal physiology, ${ }^{18}$ F-fluoroacetate is not a functional analogue of ${ }^{11} \mathrm{C}$-acetate; ${ }^{18} \mathrm{~F}$-fluoroacetate has a longer blood half-life, a rapid liver clearance and low myocardial uptake, extensive excretion into bile and urine, and suffers from skeletal defluorination resulting in skeletal uptake of the formed ${ }^{18} \mathrm{~F}$-fluoride [79]. In preclinical and clinical research, ${ }^{11} \mathrm{C}$-acetate PET imaging has been successfully used for tumour imaging in cancers of the prostate, kidney, pancreas, as well as gliomas, meningiomas and HCC $[80,81]$. In preclinical research, ${ }^{18} \mathrm{~F}$-fluoroacetate has been used for imaging of gliosis in glioblastoma, stroke, and ischemia-hypoxia associated with neuroinflammation [82]. In CWR22 tumour-bearing male $n u / n u$ mice, ${ }^{18} \mathrm{~F}$ fluoroacetate has been successfully used for prostate cancer imaging with a higher tumour-to-prostate activity ratio compared to ${ }^{11} \mathrm{C}$-acetate at $30 \mathrm{~min}$ and $2 \mathrm{~h}$ post-i.v. injection. In a patient with prostate cancer, ${ }^{18} \mathrm{~F}$-fluoroacetate was also able to detect several but not all bone metastases $[83,84]$. In other preclinical research models of breast and prostate cancers, ${ }^{11}$ C-acetoacetate uptake tended to be higher than that of ${ }^{11} \mathrm{C}$-acetate [85]. Assessment of brain ketone metabolism in rats indicated a 7 to 8 fold increase in ${ }^{11} \mathrm{C}$-acetoacetate under ketone dietary treatment $[86,87]$. Table 2 summarises the radiolabelled PC-based molecular imaging probes.

\section{PE target}

$\mathrm{PE}$ is primarily located in the inner leaflet of the membrane bilayer [88]. Like PS, this major aminophospholipid is externalised from the inner leaflet to the outer leaflet of the cell membrane during apoptosis and tumour vascular endothelium $[89,90]$. In necrosis, PE is exposed in the inner leaflet of disintegrated cell membrane.

Duramycin, a 2-kDa small protein produced by Streptovercillium cinnamoneus, has been designed in order to target PE for imaging of apoptosis or necrosis [91]. ${ }^{99 m}$ Tc-HYNIC-duramycin has been successfully used in a rat model of ischemia-reperfusion for imaging of myocardial infarction cell death [92]. ${ }^{99 \mathrm{~m}} \mathrm{Tc}$-duramycin is highly stable in vivo, and has favourable pharmacokinetics for early imaging of acute cardiac cell death at $10 \mathrm{~min}$ post-i. $v$. injection with a fast blood clearance, a low liver uptake and a high uptake in apoptotic and necrotic myocardium. Figure 6 illustrates the PE targeting ${ }^{99 \mathrm{~m}}$ Tc-duramycin molecular imaging probe in a rat model of myocardial infarction with correlation by autoradiography.

In addition to this, radiolabelled ethanolamine (i.e. ethanolamine labelled with ${ }^{11} \mathrm{C}$ or ${ }^{18} \mathrm{~F}$ ) is a potential new probe in oncology PET-CT imaging for assessment of tumour proliferation [93]. ${ }^{14}$ C-ethanolamine has been used in a variety of tumour cell types (i.e. melanoma, prostate cancer, glioblastoma multiforme, diffuse large B-cell lymphoma, colorectal adenocarcinoma). ${ }^{14} \mathrm{C}$ ethanolamine is incorporated into $\mathrm{PE}$ and has a two- to sevenfold significantly better uptake into tumour cell types than ${ }^{14} \mathrm{C}$-choline. In an in vitro model of cultured prostate cancer cells, ${ }^{14} \mathrm{C}$-ethanolamine and ${ }^{14} \mathrm{C}-\mathrm{N}, \mathrm{N}$ dimethyl-ethanolamine uptake was two- to fourfold better in androgen-dependent and proliferating PC3 cells compared to androgen-independent and growtharrested LnCap cells.

Hypericin, a PE- and PS-targeting probe, has been radiolabelled with ${ }^{64} \mathrm{Cu}$ (i.e. ${ }^{64} \mathrm{Cu}$-bis-DOTA-hypericin), ${ }^{123}$ I (i.e. mono- ${ }^{123}$ I-iodohypericin and mono- ${ }^{123}$ I-iodohypericin monocarboxylic acid), ${ }^{131}$ I (i.e. ${ }^{131}$ I-hypericin) and ${ }^{99 \mathrm{~m}} \mathrm{Tc}$ (i.e. ${ }^{99 \mathrm{~m}} \mathrm{Tc}$-hypericin) for imaging of necrosis in preclinical and clinical research as described above in the PS target section [45-50]. Table 3 summarises the PE-based radiolabelled molecular probes.

\section{PI target}

PI phospholipid is located in the inner leaflet of the membrane bilayer [94]. 1,2 Diacylglycerol (DAG) is metabolised to intermediate phosphoinositide metabolites (i.e. PA, PIP, $\mathrm{PIP}_{2}, \mathrm{PIP}_{3}$ ) including phosphatidylinositol (PI) [95]. DAG activates the intracellular protein kinase $C(P K C)$ transduction signalling pathway, which is involved in higher cortical functions (e.g. memory, learning) and cardiac functions (e.g. hypertrophic growth, ventricular remodelling).

Intact ${ }^{11}$ C-inositol (i.e. non-acetylated inositol) has been suggested as a diagnostic agent in PET imaging for evaluation of PI brain metabolism and its role as second

Table 2 Phosphatidylcholine-based radiolabelled molecular imaging probes

\begin{tabular}{|c|c|c|c|c|}
\hline Molecular target & Molecular probes & Biological functions & Isotopes & Imaging techniques \\
\hline PC & choline & choline metabolism & ${ }^{11} \mathrm{C}$ & $\operatorname{PET}(C T)$ \\
\hline PC & fluorocholine & choline metabolism & ${ }^{18} \mathrm{~F}$ & $\operatorname{PET}(C T)$ \\
\hline$P C$ & acetate & acetate metabolism & ${ }^{11} \mathrm{C}$ & $\operatorname{PET}(\mathrm{CT})$ \\
\hline PC & fluoroacetate & acetate metabolism & ${ }^{18} \mathrm{~F}$ & $\operatorname{PET}(C T)$ \\
\hline PC & acetoacetate & acetoacetate metabolism & ${ }^{11} \mathrm{C}$ & $\operatorname{PET}(C T)$ \\
\hline
\end{tabular}

PC, phosphatidylcholine; PET(CT), positron emission tomography (computed tomography). 


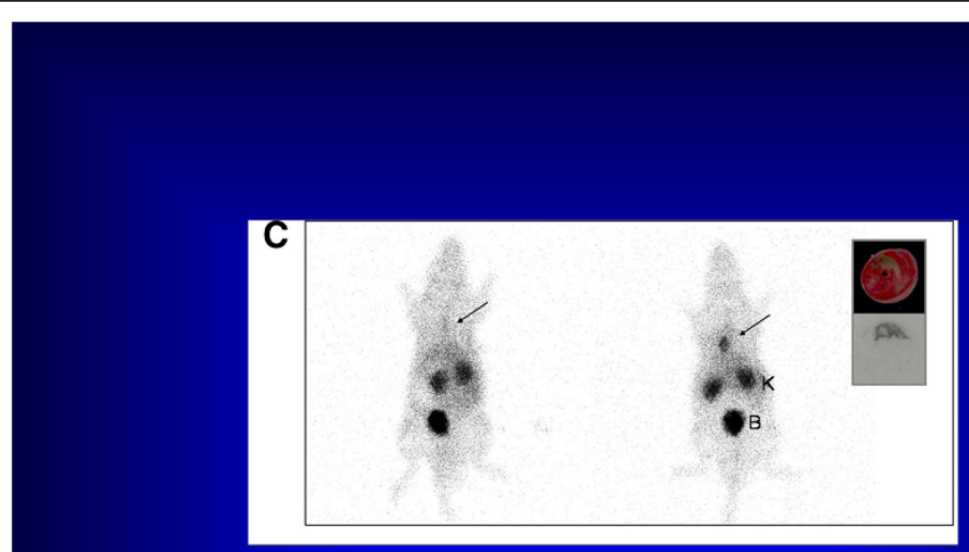

\section{PE-DURAMYCIN Imaging}

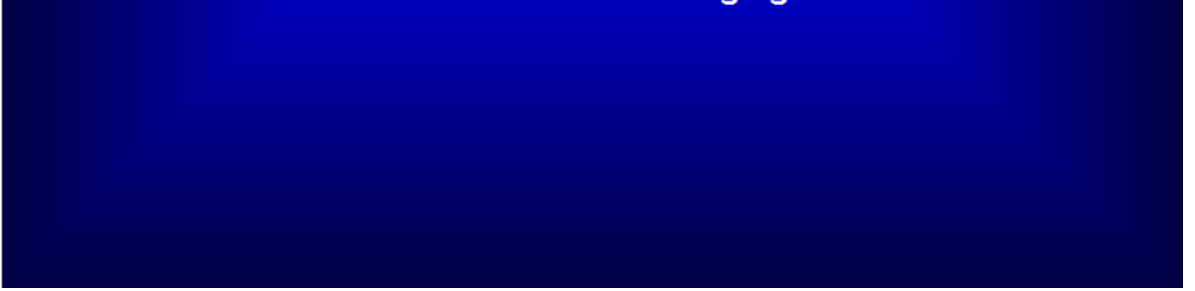

Figure 6 PE-duramycin imaging. Increased ${ }^{99 m}$ Tc-Duramycin uptake is seen in acute myocardial infarction of the rat at 120 min post-i.v. injection with excellent infarct-to-non infarct activity ratio (right). Autoradiography confirmed radioactivity uptake within the myocardial infarction. No tracer uptake is seen in the healthy rat (left). B, bladder; K, kidney. Courtesy of Pr. Zhao M (Department of Biophysics, Medical College of Wisconsin, Milwaukee, WI, USA). Previously published in the J Nucl Med 2008, 49(8):1345-52.

messenger [96]. In a rat and monkey model, $1-\left[1-{ }^{11} \mathrm{C}\right]-$ butyryl-2-palmitoyl-rac-glycerol or ${ }^{11} C$-DAG has been designed as a PI-targeting probe in PET brain imaging to visualise neuronal PI turnover $[97,98] .{ }^{11} \mathrm{C}-\mathrm{DAG}$ levels are low in the brain, and thus it may be appropriately used to visualise PI metabolism in the central nervous system. Dynamic PET imaging showed increased ${ }^{11} \mathrm{C}$-DAG uptake in the first 15 min with an equilibrium at $16 \mathrm{~min}$ in pre-stimulation and post-stimulation conditions, which is suggestive of a membrane trapping mechanism. ${ }^{11}$ C-DAG uptake increased $20 \%$ to $30 \%$ after arecoline stimulation (i.e. acetylcholine muscarinic receptor stimulation), which suggests that ${ }^{11} \mathrm{C}-\mathrm{DAG}$ is a tracer of the transduction signalling PI-mediated pathway. In resting conditions, ${ }^{11} \mathrm{C}-\mathrm{DAG}$ uptake was observed in the visual association area, and increased in the whole brain and the occipital areas after arecoline stimulation. In C6 glioma cells implanted in the rat brain, ${ }^{11} \mathrm{C}$-DAG was rapidly incorporated in the PI turnover within 5 min post-i.v injection; in a patient with astrocytoma grade III, ${ }^{11} \mathrm{C}$-DAG was gradually incorporated in the leading PI turnover and the PE-PC

Table 3 Phosphatidylethanolamine-based radiolabelled molecular imaging probes

\begin{tabular}{|c|c|c|c|c|c|c|c|}
\hline $\begin{array}{l}\text { Molecular } \\
\text { target }\end{array}$ & Molecular probes & AA & $\begin{array}{l}\text { MW } \\
(\mathrm{kDa})\end{array}$ & $\begin{array}{l}\text { Affinity } \\
\text { (M) }\end{array}$ & Biological functions & Isotopes & $\begin{array}{l}\text { Imaging } \\
\text { techniques }\end{array}$ \\
\hline$P E$ & duramycin & 19 & 2 & $10^{-9}$ & $\begin{array}{l}\text { apoptosis } \\
\text { necrosis }\end{array}$ & ${ }^{99 m} \mathrm{Tc}^{\mathrm{a}}$ & $\mathrm{SPECT}(\mathrm{CT})$ \\
\hline PE & $\begin{array}{l}\text { ethanolamine } \\
\text { N'N-dimethyl } \\
\text { ethanolamine }\end{array}$ & - & - & - & $\begin{array}{l}\text { ethanolamine metabolism (tumour } \\
\text { proliferation) }\end{array}$ & ${ }^{14} C^{b}$ & $\operatorname{PET}(\mathrm{CT})$ \\
\hline \multirow[t]{2}{*}{$P E^{c}$} & hypericin & - & 0.504 & - & necrosis & $\begin{array}{l}{ }^{123} \mathrm{I},{ }^{131} \mathrm{I} \\
99 \mathrm{~m}_{\mathrm{TC}}\end{array}$ & $\mathrm{SPECT}(\mathrm{CT})$ \\
\hline & & & & & & ${ }^{64} \mathrm{Cu}^{\mathrm{d}}$ & $\operatorname{PET}(C T)$ \\
\hline
\end{tabular}

${ }^{a}$ HYNIC has been used as a bifunctional chelating agent for the radiolabelling of duramycin. ${ }^{\mathrm{b}}$ ethanolamine or $\mathrm{N}, \mathrm{N}^{\prime}$-dimethylethanolamine labelled with ${ }^{14} \mathrm{C}$ in preclinical in vitro research may be labelled with ${ }^{11} \mathrm{C}$ or ${ }^{18} \mathrm{~F}$ for PET(CT) in vivo imaging. ${ }^{\mathrm{c}}{ }^{64} \mathrm{Cu}$-bis-DOTA-hypericin has a selective binding affinity for PS and PE (ref.45); it may be hypothesised that ${ }^{123} \mathrm{I}-{ }^{131} \mathrm{I}$ - and ${ }^{99 \mathrm{~m}} \mathrm{Tc}$-labelled hypericin derivatives bind to PS and PE. ${ }^{\mathrm{d}}$ bis-DOTA has been used as a bifunctional chelating agent for the radiolabelling of hypericin. $\mathrm{AA}$, amino acids; MW, molecular weight; $\mathrm{PE}$, phosphatidylethanolamine; $\mathrm{PET}(\mathrm{CT})$, positron emission tomography (computed tomography); SPECT(CT), single-photon emission computed tomography (computed tomography). 
secondary pool with an equilibrium period at $32-40 \mathrm{~min}$ post-iv. injection [99]. In patients with Alzheimer's disease and ischemic stroke, ${ }^{11} \mathrm{C}$-DAG evaluated the PI cortical function and neural viability, respectively. In eight patients with Alzheimer's disease, ${ }^{18}$ F-FDG PET imaging showed bilateral hypometabolism in the parieto-temporal association areas, while ${ }^{11} \mathrm{C}$-DAG imaging showed spotty uptake in the frontal lobes of the brain suggestive of compensatory plastic process in nondamaged neural circuits to degenerative cognitive impairment [100]. In five patients with cerebral infarction, dynamic PET brain imaging showed decreased

${ }^{11}$ C-DAG uptake in comparison to normal cortex [101].

${ }^{11}$ C-DAG pharmacokinetics demonstrated rapid decrease in the plasma with a peak at 40 s post-i.v. injection, and gradual increase in the brain to reach a plateau at 15 to 20 min post-i.v. injection. Reflecting neural signal transduction activity, the incorporation constant of ${ }^{11} \mathrm{C}$-DAG (k*DAG) was best correlated with the cerebral metabolic rate of $\mathrm{O}_{2}\left(\mathrm{CMRO}_{2}\right)$. Maintained PI metabolism suggested preservation of neural viability in the peri-infarct area of the ischemic stroke. Patients with subacute local brain injury, either ischemic stroke or brain tumour, also exhibited ${ }^{11} \mathrm{C}$-DAG spots located in the associative areas distant from the lesion between 2 weeks and 1 month after injury; one of the possible features of neural recovery in the intact brain related to PI metabolism in PET imaging [102].

In a rat model, ${ }^{11} \mathrm{C}$-DAG has also been used for assessing the myocardial PI turnover [103]. ${ }^{11} \mathrm{C}$-DAG incorporation into intermediate PI metabolites was seen both in the infarcted and the non-infarcted myocardium at 7 days after myocardial infarction. Furthermore, ${ }^{11} \mathrm{C}$-DAG has been used to evaluate the PI-mediated angiotensin II signalling pathway. In a rat model of infarcted myocardium, ${ }^{11} \mathrm{C}-\mathrm{DAG}$ assessed the effect of angiotensin-converting enzyme inhibitor (i.e. captropril) on activated PI metabolism in order to reduce left ventricular remodelling in the early phase of myocardial infarction [104]. After 3 weeks of treatment with captropril, a significant decrease of ${ }^{11} \mathrm{C}$-DAG uptake was seen in the infarcted myocardium compared to the non-infarcted myocardium, while ${ }^{201} \mathrm{Tl}$ imaging showed decreased uptake in the infarcted myocardium with and without captopril treatment. In patients with myocardial infarction, ${ }^{11} \mathrm{C}-\mathrm{DAG}$ has been used to evaluate the PI myocardial turnover and the left ventricular remodelling [105]. In 13 patients with myocardial infarction, ${ }^{11} \mathrm{C}$-DAG was significantly correlated with the myocardium-to-left atrium chamber ratio, the left ventricle ejection fraction, and the brain natriuretic peptide concentration. Significant increase of ${ }^{11} \mathrm{C}$-DAG uptake was seen in the remote viable region of myocardial infarction patients compared to healthy subjects. DAG has also been labelled with ${ }^{18} \mathrm{~F}$ to trace the PI metabolism into the ventricular myocardium [106]. ${ }^{18} \mathrm{~F}$ has a longer half-life, and ${ }^{18}$ F-DAG may be more useful for clinical routine than ${ }^{11} \mathrm{C}$-DAG. In the rat myocardium, $3,5,10$, and $30 \mathrm{~min}$ after i.v. injection of 1-[4-[18F]fluorobutyryl]-2-palmitoylglycerol (C4, C16), ${ }^{18} \mathrm{~F}$-DAG reflected the myocardium PI metabolism in the early phase (3 to $5 \mathrm{~min}$ ); in the late phase ( $\geq 30 \mathrm{~min}$ ) after i.v. injection, ${ }^{18}$ F-DAG may also reflect the PE metabolism. Quantification of PI metabolism requires further optimization with a ${ }^{18} \mathrm{~F}$-radiolabelled DAG compound closer to the PI metabolism than ${ }^{18} \mathrm{~F}$ DAG (C4, C16) [106]. Table 4 summarises the PI-based radiolabelled molecular imaging probes.

\section{SM target}

SM is a cholinophospholipid located in the outer leaflet of the membrane bilayer [19]. Liposomes composed of SM have been experimentally used for tumour imaging. In a mouse tumour model, serum stable SM liposomesencapsulating ${ }^{67} \mathrm{Ga}$ prepared in a lipid phase with cholesterol (SM/cholesterol molar ratio, 2:1) enhanced blood circulation and increased ${ }^{67} \mathrm{Ga}$ delivery to the tumour [107]. Tumour-to-blood activity ratio $(T / B)$ and tumour index $(\mathrm{TI}=T / B \times$ percentage dose per gram) were higher at 24,48 and $72 \mathrm{~h}$ post-injection.

Neutral SM liposomes with encapsulated ${ }^{67} \mathrm{Ga}$ in an aqueous phase offer better radiolabelling properties and ${ }^{67} \mathrm{Ga}$ accumulation for tumour imaging [108]. Table 5 summarises the SM-based radiolabelled molecular imaging probes.

\section{Conclusion}

In nuclear medicine, the transbilayer phospholipid targets are used in preclinical and clinical research for SPECT-CT and PET-CT molecular imaging with radiolabelled probes to assess key biological functions:

1. the PS target allows the visualisation, characterisation, and measurement of apoptosis or necrosis, and thrombosis with radiolabelled annexin $\mathrm{V}$ and the ${ }^{99 \mathrm{~m}} \mathrm{Tc}$

Table 4 Phosphatidylinositol-based radiolabelled molecular imaging probes

\begin{tabular}{lllll}
\hline Molecular target & Molecular probes & Biological functions & Isotopes & Imaging techniques \\
\hline $\mathrm{PI}$ & inositol $^{\mathrm{a}}$ & $\mathrm{Pl}$ brain metabolism & ${ }^{11} \mathrm{C}$ & $\mathrm{PET}(\mathrm{CT})$ \\
$\mathrm{PI}$ & $\mathrm{DAG}$ & $\mathrm{Pl}$ myocardial turnover & ${ }^{11} \mathrm{C},{ }^{18} \mathrm{~F}$ & $\mathrm{PET}(\mathrm{CT})$ \\
$\mathrm{PI}$ & $\mathrm{DAG}$ & $\mathrm{Pl}$ neuronal turnover & ${ }^{11} \mathrm{C}$ & $\mathrm{PET}(\mathrm{CT})$ \\
\hline
\end{tabular}

\footnotetext{
a intact inositol: no acetylated analogues. DAG, diacylglycerol; PET(CT), positron emission tomography (computed tomography); PI, phosphatidylinositol.
} 
Table 5 Sphyngomyelin-based radiolabelled molecular imaging probes

\begin{tabular}{|c|c|c|c|c|}
\hline Molecular target & Molecular probes & Biological functions & Isotopes & Imaging techniques \\
\hline$\overline{S M}$ & liposomes $^{a}$ & tumour imaging & ${ }^{67} \mathrm{Ga}$ & SPECT(CT) \\
\hline
\end{tabular}

or ${ }^{18} \mathrm{~F}$-labelled C2A domain of synaptotagmin I and the ${ }^{99 \mathrm{~m}}$ Tc-labelled HYNIC-lactadherin; ${ }^{99 \mathrm{~m}}$ Tc-labelled synthetic PSBP-6-SAAC probe has been designed for molecular imaging of cell death. PS targeting probes may allow imaging of tumour endothelium vasculature with ${ }^{74}$ As-bavituximab. ${ }^{77 / 76}$ As-bavituximab may also serve for $\beta$ - radioimmunotherapy of tumours with PS exposed endothelium tumour vasculature.

2. the PE target allows imaging of apoptosis or necrosis with ${ }^{99 \mathrm{~m}} \mathrm{Tc}-\mathrm{HYNIC}$-duramycin. It may also allow tumour imaging with radiolabelled ethanolamine and $\mathrm{N}$, N' dimethylethanolamine.

3. the PS and PE targets allow imaging of necrosis with the radiolabelled ${ }^{64} \mathrm{Cu}$-bis-DOTA hypericin.

4. the PC target allows assessment of choline metabolism with ${ }^{11} \mathrm{C}$-choline or ${ }^{18} \mathrm{~F}$-fluorocholine, and also the evaluation of the acetate and acetoacetate metabolism with ${ }^{11} \mathrm{C}$-acetate or ${ }^{18} \mathrm{~F}$-fluoroacetate and ${ }^{11} \mathrm{C}$-acetoacetate.

5. the PI target allows evaluation of the neuronal and myocardial PI turnover with ${ }^{11} \mathrm{C}$ or ${ }^{18} \mathrm{~F}$-labelled DAG, and also with ${ }^{11} \mathrm{C}$-inositol.

6. the SM target may be used with liposomes encapsulating ${ }^{67} \mathrm{Ga}$ for imaging purposes.

7. Translation of preclinical research to clinical research will be necessary to optimally assess the pharmacokinetics of radiolabelled probes for molecular imaging of transbilayer phospholipids.

\section{Abbreviations}

AA: amino acids; ATP: adenosine triphosphate; CT: computed tomography; C2A-GST: C2A Synaptotagmin domain I glutathione-S-transferase; CA4P: combretastatin A4 phosphate; DAG: diacylglycerol; DOTA: 1,4,7,10tetraazacyclododecane-N, N', N", N"'-tetraacetic acid; ECM: external leaflet of the cell membrane; FITC: fluorescein isothiocyanate; ${ }^{18} \mathrm{~F}-\mathrm{FCH}:{ }^{18} \mathrm{~F}-$ fluorocholine; ${ }^{18}$ F-FDG: ${ }^{18} \mathrm{~F}$-fluorodeoxyglucose; kDa: kilodalton; HYNIC: hydrazinonicotinamide; i.e.: id est (in example with complete enumeration); e.g.: exampli gratia (for example with incomplete enumeration); ICM: internal leaflet of the cell membrane; M: molar; $10^{-9} \mathrm{M}$ : nanomolar; MI: molecular imaging; MRI: magnetic resonance imaging; MW: molecular weight; NSCLC: non-small cell lung cancer; PA: phosphatidic acid; PC: phosphatidylcholine; PE: phosphatidylethanolamine; PET-CT: positron emission tomographycomputed tomography; p.i: post-intra-venous injection; PI: phosphatidylinositol; PIP: phosphatidylinositol 4-phosphate; PIP 2: phosphatidylinositol 4,5-diphosphate; PIP 3: phosphatidylinositol 3,4,5triphosphate; PS: phosphatidylserine; SAAC: single amino acid chelator; SM: sphyngomyelin; SPECT-CT: single-photon emission computed tomographycomputed tomography; TRAIL: tumour necrosis factor-related apoptosisinducing ligand; TUNEL: terminal deoxynucleotidyl transferase-mediated dUTP nick end labelling.
}

\section{Acknowledgements}

The authors would like to acknowledge the contribution of Dr. Kimberley J. Blackwood (PhD), post-doctoral associate at The University of Western
Ontario and The Lawson Health Research Institute, for her valuable assistance in the manuscript editing.

\section{Author details}

${ }^{1}$ Department of Medical Imaging, The University of Western Ontario, London, ON, Canada ${ }^{2}$ Departments of Medical BioPhysics and Physics, Lawson Health Research Institute, The University of Western Ontario, London, ON, Canada

\section{Authors' contributions}

TB has made substantial contribution in drafting the manuscript. FP has made substantial contribution in reviewing the manuscript. All authors read and approved the final manuscript.

\section{Authors' information}

TB is nuclear medicine physician (MD, PhD) and Adjunct Professor at The University of Western Ontario in the department of Medical Imaging (London, ON, Canada).

FP is imaging program leader (PhD), Assistant Scientific Director at The Lawson Health Research Institute (LHRI), Professor at The University of Western Ontario in the departments of Medical Imaging, Medical BioPhysics and Physics, and Chief Medical Physicist at St. Joseph's Health Care and London Health Sciences Centre (London, ON, Canada).

\section{Competing interests}

The authors declare that they have no competing interests.

Received: 20 May 2011 Accepted: 22 August 2011

Published: 22 August 2011

\section{References}

1. Jain KK: Personalized medicine. Curr Opin Mol Ther 2002, 4:548-558, Review.

2. Basu S: Personalized versus evidence-based medicine with PET-based imaging. Nat Rev Clin Oncol 2010, 7:665-668.

3. Hoffman JM, Gambhir SS: Molecular imaging: the vision and opportunity for radiology in the future. Radiology 2007, 244:39-47, Review.

4. Anderson CJ: A new vision for the MICoE. J NuCl Med 2010, 51, 19N, 24N.

5. Hnatowich DJ: Observations on the role of nuclear medicine in molecular imaging. J Cell Biochem Supp/ 2002, 39:18-24, Review.

6. Pappas $\mathrm{V}$ : Renewed energy for nuclear medicine and molecular imaging. J Nucl Med 2011, 52:20N.

7. Pomper MG, Gelovani JG: Molecular Imaging in Oncology Informa Healthcare USA, Inc; 2008.

8. Mankoff ADavid: A definition of molecular imaging. J NuCl Med 2007 $48: 18 \mathrm{~N}, 21 \mathrm{~N}$.

9. Reubi JC, Maecke HR: Peptide-based probes for cancer imaging. J NuCl Med 2008, 49:1735-1738, Review.

10. Tait JF: Imaging of Apoptosis. J Nucl Med 2008, 49:1573-1576.

11. Anderson CJ, Bulte JW, Chen K, Chen X, Khaw BA, Shokeen M, Wooley KL, VanBrocklin HF: Design of targeted cardiovascular molecular imaging probes. J Nucl Med 2010, 51(Suppl 1):3S-17S.

12. Eckelman WC, Reba RC, Kelloff GJ: Targeted imaging: an important biomarker for understanding disease progression in the era of personalized medicine. Drug Discov Today 2008, 13:748-759.

13. Vance JE, Steenbergen R: Metabolism and functions of phosphatidylserine. Prog Lipid Res 2005, 44:207-234, Review.

14. Ulrich AS: Biophysical aspects of using liposomes as delivery vehicles. Biosci Rep 2002, 22:129-150, Review.

15. Phillips WT, Goins BA, Bao A: Radioactive liposomes. Wiley Interdiscip Rev Nanomed Nanobiotechnol 2009, 1:69-83, Review.

16. Singer SJ, Nicolson GL: The fluid mosaic model of the structure of cell membranes. Science 1972, 175:720-731. 
17. Bagatolli LA, Ipsen JH, Simonsen AC, Mouritsen OG: An outlook on organization of lipids in membranes: searching for a realistic connection with the organization of biological membranes. Prog Lipid Res 2010, 49:378-389.

18. Vereb G, Szöllosi J, Matkó J, Nagy P, Farkas T, Vigh L, Mátyus L, Waldmann TA, Damjanovich S: Dynamic, yet structured: the cell membrane three decades after the Singer-Nicolson model. Proc Natl Acad Sci USA 2003, 100:8053-8058, Review.

19. Yamaji-Hasegawa A, Tsujimoto M: Asymmetric distribution of phospholipids in biomembranes. Biol Pharm Bull 2006, 29:1547-1553, Review.

20. Balasubramanian K, Schroit AJ: Aminophospholipid asymmetry: a matter of life and death. Annu Rev Physiol 2003, 65:701-734, Review.

21. Garcia-Manyes S, Redondo-Morata L, Oncins G, Sanz F: Nanomechanics of lipid bilayers: heads or tails? J Am Chem Soc 2010, 132:12874-12886.

22. van Meer G, Voelker DR, Feigenson GW: Membrane lipids: where they are and how they behave. Nat Rev Mol Cell Biol 2008, 9:112-124, Review.

23. Groves AM, Win T, Haim SB, Ell PJ: Non-[18F]FDG PET in clinical oncology. Lancet Oncol 2007, 8:822-830, Review.

24. Belhocine TZ, Blankenberg FG: The imaging of apoptosis with the radiolabelled annexin A5: a new tool in translational research. Curr Clin Pharmacol 2006, 1:129-137, Review.

25. Zwaal RF, Schroit AJ: Pathophysiologic implications of membrane phospholipid asymmetry in blood cells. Blood 1997, 89:1121-1132, Review.

26. Lahorte CM, Vanderheyden JL, Steinmetz N, Van de Wiele C, Dierckx RA Slegers G: Apoptosis-detecting radioligands: current state of the art and future perspectives. Eur J Nucl Med Mol Imaging 2004, 31:887-919, Review.

27. Belhocine T, Steinmetz N, Hustinx R, Bartsch P, Jerusalem G, Seidel L, Rigo $P$, Green A: Increased uptake of the apoptosis-imaging agent $(99 \mathrm{~m})$ Tc recombinant human Annexin $V$ in human tumors after one course of chemotherapy as a predictor of tumor response and patient prognosis. Clin Cancer Res 2002, 8:2766-2774.

28. Boersma HH, Kietselaer BL, Stolk LM, Bennaghmouch A, Hofstra L, Narula J, Heidendal GA, Reutelingsperger CP: Past, present, and future of annexin A5: from discovery to clinical applications. J Nucl Med 2005, 46:2035-2050, Review.

29. Sarda-Mantel L, Coutard M, Rouzet F, Raguin O, Vrigneaud JM, Hervatin F, Martet G, Touat Z, Merlet P, Le Guludec D, Michel JB: 99mTc.annexin-V functional imaging of luminal thrombus activity in abdominal aortic aneurysms. Arterioscler Thromb Vasc Biol 2006, 26:2153-2159.

30. Kartachova MS, Valdés Olmos RA, Haas RL, Hoebers FJ, van Herk M, Verheij M: 99mTc-HYNIC-rh-annexin-V scintigraphy: visual and quantitative evaluation of early treatment-induced apoptosis to predict treatment outcome. Nucl Med Commun 2008, 29:39-44.

31. Vermeersch $\mathrm{H}$, Ham H, Rottey S, Lahorte C, Corsetti F, Dierckx R, Steinmetz N, Van de Wiele C: Intraobserver, interobserver, and day-to-day reproducibility of quantitative $99 \mathrm{mTC}$-HYNIC annexin $\mathrm{V}$ imaging in head and neck carcinoma. Cancer Biother Radiopharm 2004, 19:205-210.

32. Tait JF, Smith C, Levashova Z, Patel B, Blankenberg FG, Vanderheyden J Improved detection of cell death in vivo with annexin $\mathrm{V}$ radiolabeled by site-specific methods. J Nucl Med 2006, 47:1546-1553.

33. Zhao M, Zhu X, Ji S, Zhou J, Ozker KS, Fang W, Molthen RC, Hellman RS: $99 \mathrm{mTc}$-labelled C2A domain of synaptotagmin I as a target-specific molecular probe for noninvasive imaging of acute myocardial infarction. J Nucl Med 2006, 47:1367-1374.

34. Zhu X, Li Z, Zhao M: Imaging acute cardiac cell death: temporal and spatial distribution of $99 \mathrm{mTc}$-labelled C2A in the area at risk after myocardial ischemia and reperfusion. J Nucl Med 2007, 48:1031-1036.

35. Fang W, Wang F, Ji S, Meier HT, Hellman RS, Brindle KM, Davletov B, Zhao M: SPECT imaging of myocardial infarction using $99 \mathrm{mT}$ T-labelled C2A domain of synaptotagmin I a porcine ischemia-reperfusion model. Nucl Med Biol 2007, 34:917-923.

36. Zhu X, Migrino RQ, Hellman RS, Brahmbhatt $T$, Zhao M: Early uptake of 99mTc-C2A: in the acute phase of myocardial infarction as a prognostic indicator for follow-up cardiac dysfunction. Nucl Med Commun 2008, 29:764-769.

37. Wang F, Fang $W$, Zhao $M$, Wang Z, Ji S, Li Y, Zheng Y: Imaging paclitaxel (chemotherapy)-induced tumor apoptosis with $99 \mathrm{mTc}$ C2A, a domain of synaptotagmin I: a preliminary study. Nucl Med Biol 2008, 35:359-364

38. Wang F, Fang W, Zhang MR, Zhao M, Liu B, Wang Z, Hua Z, Yang M, Kumata K, Hatori A, Yamasaki T, Yanamoto K, Suzuki K: Evaluation of chemotherapy response in VX2 rabbit lung cancer with $18 \mathrm{~F}$-labelled C2A domain of synaptotagmin I. J Nucl Med 2011, 52:592-599.

39. Tavaré $R$, Torres Martin De Rosales R, Blower PJ, Mullen GE: Efficient sitespecific radiolabeling of a modified C2A domain synaptotagmin I with [99mTc(CO)3]+: a new radiopharmaceutical for imaging cell death. Bioconjug Chem 2009, 20:2071-2081.

40. Ran S, Downes A, Thorpe PE: Increased exposure of anionic phospholipids on the surface of tumor blood vessels. Cancer Res 2002, 62:6132-6140.

41. Ran S, Thorpe PE: Phosphatidylserine is a marker of tumor vasculature and a potential target for cancer imaging and therapy. Int J Radiat Oncol Biol Phys 2002, 54:1479-1484.

42. Ran S, He J, Huang X, Soares M, Scothorn D, Thorpe PE: Antitumor effects of a monoclonal antibody that binds anionic phospholipids on the surface of tumor blood vessels in mice. Clin Cancer Res 2005, 11:1551-1562.

43. Jennewein M, Lewis MA, Zhao D, Tsyganov E, Slavine N, He J, Watkins L, Kodibagkar VD, O'Kelly S, Kulkarni P, Antich PP, Hermanne A, Rösch F, Mason RP, Thorpe PE: Vascular imaging of solid tumors in rats with a radioactive arsenic-labelled antibody that binds exposed phosphatidylserine. Clin Cancer Res 2008, 14:1377-1385.

44. Chopra A: [74]-Labeled monoclonal antibody against anionic phospholipids. Molecular Imaging and Contrast Agent Database (MICAD) [Internet] Bethesda (MD): National Center for Biotechnology Information (US); 2004-2010.

45. Song S, Xiong C, Zhou M, Lu W, Huang Q, Ku G, Zhao J, Flores LG Jr, Ni Y Li C: Small-animal PET of tumor damage induced by photothermal ablation with 64cu-bis-dota-hypericin. J Nucl Med 2011, 52:792-799.

46. Ni Y, Huyghe D, Verbeke $K$, de Witte PA, Nuyts J, Mortelmans L, Chen F, Marchal G, Verbruggen AM, Bormans GM: First preclinical evaluation of mono-[123I]iodohypericin as a necrosis-avid tracer agent. Eur J Nucl Med Mol Imaging 2006, 33:595-601.

47. Fonge $H$, Vunckx $K$, Wang $H$, Feng $Y$, Mortelmans L, Nuyts J, Bormans G, Verbruggen $\mathrm{A}$, Ni Y: Non-invasive detection and quantification of acute myocardial infarction in rabbits using mono-[123l]iodohypericin microSPECT. Eur Heart J 2008, 29:260-269.

48. Li J, Sun Z, Zhang J, Shao H, Miranda Cona M, Wang H, Marysael T, Chen F, Prinsen K, Zhou L, Huang D, Nuyts J, Yu J, Meng B, Bormans G, Fang Z, de Witte P, Li Y, Verbruggen A, Wang X, Mortelmans L, Xu K, Marchal G, Ni Y: A dual-targeting anticancer approach: soil and seed principle. Radiology 2011, 260:799-807.

49. Chopra A: [99mTc]-Mercaptoacetyldiglycyl-1,5-diaminopentylene hypericincarboxamide. Molecular Imaging and Contrast Agent Database (MICAD) [Internet] Bethesda (MD): National Center for Biotechnology Information (US); 2004-2010.

50. Fonge $H$, Jin L, Wang H, Bormans G, Ni Y, Verbruggen A: Synthesis and preliminary biological evaluation of a $99 \mathrm{mTc}$-labelled hypericin derivative as a necrosis avid imaging agent. J Label Comp Radiopharm 2008, 51:33-40.

51. Häggqvist B, Näslund J, Sletten K, Westermark GT, Mucchiano G, Tjernberg LO, Nordstedt C, Engström U, Westermark P: Medin: an integral fragment of aortic smooth muscle cell-produced lactadherin forms the most common human amyloid. Proc Natl Acad Sci USA 1999, 96:8669-8674.

52. Hou J, Fu Y, Zhou J, Li W, Xie R, Cao F, Gilbert GE, Shi J: Lactadherin functions as a probe for phosphatidylserine exposure and as an anticoagulant in the study of stored platelets. Vox Sang 2011, 100:187-195.

53. Schutters $K$, Reutelingsperger C: Phosphatidylserine targeting for diagnosis and treatment of human diseases. Apoptosis 2010, 15:1072-1082, Review.

54. Shi J, Shi Y, Waehrens LN, Rasmussen JT, Heegaard CW, Gilbert GE: Lactadherin detects early phosphatidylserine exposure on immortalized leukemia cells undergoing programmed cell death. Cytometry A 2006, 69:1193-1201.

55. Waehrens LN, Heegaard CW, Gilbert GE, Rasmussen JT: Bovine lactadherin as a calcium-independent imaging agent of phosphatidylserine expressed on the surface of apoptotic HeLa cells. J Histochem Cytochem 2009, 57:907-914.

56. Falborg L, Waehrens LN, Alsner J, Bluhme H, Frøkiaer J, Heegaard CW, Horsman MR, Rasmussen JT, Rehling M: Biodistribution of 99mTc-HYNIC- 
lactadherin in mice-a potential tracer for visualizing apoptosis in vivo. Scand I Clin Lab Invest 2010, 70:209-216.

57. Xiong C, Brewer K, Song S, Zhang R, Lu W, Wen X, Li C: Peptide-based imaging agents targeting phosphatidylserine for the detection of apoptosis. J Med Chem 2011, 54:1825-1835.

58. Price DT, Coleman RE, Liao RP, Robertson CN, Polascik TJ, DeGrado TR: Comparison of [18F]fluorocholine and [18F]fluorodeoxyglucose for positron emission tomography of androgen dependent and androgen independent prostate cancer. J Urol 2002, 168:273-280.

59. Leung K: $\left[{ }^{11} \mathrm{C}\right]$ Choline. Molecular Imaging and Contrast Agent Database (MICAD) [Internet] Bethesda (MD): National Center for Biotechnology Information (US); 2004-2011.

60. Leung K: $\left[{ }^{18} \mathrm{~F}\right]$ Fluorocholine. Molecular Imaging and Contrast Agent Database (MICAD) [Internet] Bethesda (MD): National Center for Biotechnology Information (US); 2004-2011.

61. DeGrado TR, Reiman RE, Price DT, Wang S, Coleman RE: Pharmacokinetics and radiation dosimetry of 18F-fluorocholine. J Nucl Med 2002, 43:92-96.

62. Mertens K, Slaets D, Lambert B, Acou M, De Vos F, Goethals I: PET with (18) F-labelled choline-based tracers for tumour imaging: a review of the literature. Eur J Nucl Med Mol Imaging 2010, 37:2188-2193.

63. Chiti A, Picchio M: The rising PET: the increasing use of choline PET/CT in prostate cancer. Eur J Nucl Med Mol Imaging 2011, 38:53-54.

64. Picchio M, Briganti A, Fanti S, Heidenreich A, Krause BJ, Messa C, Montorsi F, Reske SN, Thalmann GN: The role of choline positron emission tomography/computed tomography in the management of patients with prostate-specific antigen progression after radical treatment of prostate cancer. Eur Urol 2011, 59:51-60.

65. Kwee SA, Coel MN, Lim J, Ko JP: Combined use of F-18 fluorocholine positron emission tomography and magnetic resonance spectroscopy for brain tumor evaluation. J Neuroimaging 2004, 14:285-289.

66. Hara T, Kondo T, Hara T, Kosaka N: Use of 18F-choline and 11C-choline as contrast agents in positron emission tomography imaging-guided stereotactic biopsy sampling of gliomas. J Neurosurg 2003, 99:474-479.

67. Kwee SA, Ko JP, Jiang CS, Watters MR, Coel MN: Solitary brain lesions enhancing at MR imaging: evaluation with fluorine 18 fluorocholine PET. Radiology 2007, 244:557-565.

68. Lam WW, Ng DC, Wong WY, Ong SC, Yu SW, See SJ: Promising role of [18F] fluorocholine PET/CT vs [18F] fluorodeoxyglucose PET/CT in primary brain tumors-Early experience. Clin Neurol Neurosurg 2011, 113:156-161.

69. Kuang Y, Salem N, Tian H, Kolthammer JA, Corn DJ, Wu C, Wang F, Wang Y, Lee Z: Imaging lipid synthesis in hepatocellular carcinoma with [methyl11c]choline: correlation with on vivo metabolic studies. J Nucl Med 2011, 52:98-106

70. Salem N, Kuang Y, Wang F, Maclennan GT, Lee Z: PET imaging of hepatocellular carcinoma with 2-deoxy-2[18F]fluoro-d-deoxyglucose, 6deoxy-6[18F] fluoro-d-glucose, [1-11C]-acetate and [N-methyl-11C]choline. Q J Nucl Med Mol Imaging 2009, 53:144-156.

71. Yamamoto Y, Nishiyama Y, Kameyama R, Okano K, Kashiwagi H, Deguchi A, Kaji M, Ohkawa M: Detection of hepatocellular carcinoma using 11Ccholine PET: comparison with 18F-FDG PET. J Nucl Med 2008, 49:1245-1248.

72. Talbot JN, Gutman F, Fartoux L, Grange JD, Ganne N, Kerrou K, Grahek D, Montravers F, Poupon R, Rosmorduc O: PET/CT in patients with hepatocellular carcinoma using [(18)F]fluorocholine: preliminary comparison with [(18)F]FDG PET/CT. Eur J Nucl Med Mol Imaging 2006, 33:1285-1289.

73. Talbot JN, Fartoux L, Balogova S, Nataf V, Kerrou K, Gutman F, Huchet V, Ancel D, Grange JD, Rosmorduc O: Detection of hepatocellular carcinoma with PET/CT: a prospective comparison of 18F-fluorocholine and 18FFDG in patients with cirrhosis or chronic liver disease. J Nucl Med 2010, 51:1699-1706.

74. Leung K: [11C]Acetate. Molecular Imaging and Contrast Agent Database (MICAD) [Internet] Bethesda (MD): National Center for Biotechnology Information (US): 2004-2010.

75. Yoshimoto M, Waki A, Yonekura Y, Sadato N, Murata T, Omata N, Takahashi N, Welch MJ, Fujibayashi Y: Characterization of acetate metabolism in tumor cells in relation to cell proliferation: acetate metabolism in tumor cells. Nucl Med Biol 2001, 28:117-122.

76. Swinnen JV, Van Veldhoven PP, Timmermans L, De Schrijver E, Brusselmans K, Vanderhoydonc F, Van de Sande T, Heemers H, Heyns W,
Verhoeven G: Fatty acid synthase drives the synthesis of phospholipids partitioning into detergent-resistant membrane microdomains. Biochem Biophys Res Commun 2003, 302:898-903.

77. Leung K: [11C]Acetoacetate. Molecular Imaging and Contrast Agent Database (MICAD) [Internet] Bethesda (MD): National Center for Biotechnology Information (US); 2004-2010.

78. Leung K: 2-[18F]Fluoroacetate. Molecular Imaging and Contrast Agent Database (MICAD) [Internet] Bethesda (MD): National Center for Biotechnology Information (US); 2004-2010, 2007 Mar 22 [updated 2008 Jun 24].

79. Lindhe O, Sun A, Ulin J, Rahman O, Långström B, Sörensen J: [(18)F] Fluoroacetate is not a functional analogue of [(11)C]acetate in normal physiology. Eur I Nucl Med Mol Imaging 2009, 36:1453-1459.

80. Jadvar H: Prostate cancer: PET with 18F-FDG, 18F. or 11C-Acetate, and 18F. or 11C-choline. J Nucl Med 2011, 52:81-89.

81. Liu RS: Clinical applications of C-11-acetate in oncology [abstract]. Clin Positron Imaging 2000, 3:185.

82. Marik J, Ogasawara A, Martin-McNulty B, Ross J, Flores JE, Gill HS, Tinianow JN, Vanderbilt AN, Nishimura M, Peale F, Pastuskovas C, Greve JM, van Bruggen N, Williams SP: PET of glial metabolism using 2-18Ffluoroacetate. J Nucl Med 2009, 50:982-989.

83. Ponde DE, Dence CS, Oyama N, Kim J, Tai YC, Laforest R, Siegel BA, Welch MJ: 18F-fluoroacetate: a potential acetate analog for prostate tumor imaging-in vivo evaluation of $18 \mathrm{~F}$-fluoroacetate versus $11 \mathrm{C}$ acetate. J Nucl Med 2007, 48:420-428.

84. Matthies A, Ezziddin S, Ulrich EM, Palmedo H, Biersack HJ, Bender $H$, Guhlke S: Imaging of prostate cancer metastases with 18F-fluoroacetate using PET/CT. Eur J Nucl Med Mol Imaging 2004, 31:797.

85. Authier S, Tremblay S, Dumulon V, Dubuc C, Ouellet R, Lecomte R, Cunnane SC, Benard F: $[(11) C]$ Acetoacetate utilization by breast and prostate tumors: a PET and biodistribution study in mice. Mol Imaging Biol 2008, 10:217-223.

86. Pifferi F, Tremblay S, Plourde M, Tremblay-Mercier J, Bentourkia M, Cunnane SC: Ketones and brain function: possible link to polyunsaturated fatty acids and availability of a new brain PET tracer, 11C-acetoacetate. Epilepsia 2008, 49(Suppl 8):76-79, Review.

87. Bentourkia M, Tremblay S, Pifferi F, Rousseau J, Lecomte R, Cunnane S: PET study of $11 \mathrm{C}$-acetoacetate kinetics in rat brain during dietary treatments affecting ketosis. Am J Physiol Endocrinol Metab 2009, 296:E796-801.

88. Vance JE: Phosphatidylserine and phosphatidylethanolamine in mammalian cells: two metabolically related aminophospholipids. J Lipid Res 2008, 49:1377-1387, Review.

89. Marconescu A, Thorpe PE: Coincident exposure of phosphatidylethanolamine and anionic phospholipids on the surface of irradiated cells. Biochim Biophys Acta 2008, 1778:2217-2224.

90. Stafford JH, Thorpe PE: Increased exposure of phosphatidylethanolamine on the surface of tumor vascular endothelium. Neoplasia 2011, 13:299-308.

91. Leung K: ${ }^{99 \mathrm{~m}} \mathrm{Tc}$-(Hydrazinonicotinic acid-duramycin)(tricine)(TPPTS). Molecular Imaging and Contrast Agent Database (MICAD) [Internet] Bethesda (MD): National Center for Biotechnology Information (US); 2004-2010.

92. Zhao M, Li Z, Bugenhagen S: 99mTc-labelled duramycin as a novel phosphatidylethanolamine-binding molecular probe. J Nucl Med 2008, 49:1345-1352.

93. Mintz A, Wang L, Ponde DE: Comparison of radiolabeled choline and ethanolamine as probe for cancer detection. Cancer Biol Ther 2008, 7:742-747

94. Vance JE, Vance DE: Phospholipid biosynthesis in mammalians cells. Biochem Cell Biol 2004, 82:113-128, Review.

95. Imahori Y, Fujii R, Ueda S, Matsumoto K, Wakita K, Ido T, Nariai T, Nakahashi H: Membrane trapping of carbone-11-labelled 1,2diacylglycerols as a basic concept for assessing phosphatidylinositol turnover in neurotransmission process. J Nucl Med 1992, 33:413-422.

96. Sasaki T, Ogihara-Umeda I, Kojima S, Nishigori H: Sequential enzymatic synthesis and biodistribution of radiolabelled inositol and inositol analogs. Int J Rad Appl Instrum A 1991, 42:97-101.

97. Fujii $R$, Ueda S, Kanatsuna T, Imahori $Y$, Ido T, Wakita K, Horii $H$, Yagyu T, Higashi N, Mabuchi H, Ohmori Y: [Carbon-11 labelled diacylglycerol for signal transduction imaging by positron CT: evaluation of the quality and safety for clinical use]. Kaku lgaku 1995, 32:191-198, Japanese. 
98. Imahori Y, Fujii R, Ueda S, Ohmori Y, Wakita K, Matsumoto K: Phosphoinositide turnover imaging linked to muscarinic cholinergic receptor in the central nervous system by positron emission tomography. J Nucl Med 1993, 34:1543-1551.

99. Imahori Y, Ohmori Y, Fujii R, Matsumoto K, Ueda S: Rapid incorporation of carbon-11-labeled diacylglycerol as a probe of signal transduction in glioma. Cancer Res 1995, 55:4225-4229.

100. Kondo M, Imahori Y, Mori S, Ueda Y, Fujii R, Nakajima K: Aberrant plasticity in Alzheimer's disease. Neuroreport 1999, 10:1481-1484.

101. Matsumoto K, Imahori Y, Fujii R, Ohmori Y, Sekimoto T, Ueda S, Mineura K: Evaluation of phosphoinositides turnover on ischemic human brain with 1-[1-11]-butyryl-2-palmitoyl-rac-glycerol using PET. J Nucl Med 1999, 40:1590-1594.

102. Imahori Y, Fujii R, Kondo M, Ohmori Y, Nakajima K: Neural features of recovery from CNS injury revealed by PET in human brain. Neuroreport 1999, 10:117-121.

103. Chida M, Kagaya Y, Imahori Y, Namiuchi S, Fujii R, Fukuchi M, Takahashi C, Tezuka F, Ido T, Shirato K: Visualization of myocardial phosphoinositide turn over with 1-[1-(11)C]-butyryl-2-palmitoyl-rac-glycerol in rats with myocardial infarction. J Nucl Med 2000, 41:2063-2068.

104. Kagaya Y, Chida M, Imahori Y, Fujii R, Namiuchi S, Takeda M, Yamane Y, Otani H, Watanabe J, Fukuchi M, Tezuka F, Ido T, Shirato K: Effect of angiotensin converting enzyme inhibition on myocardial phosphoinositides metabolism visualised with 1-[1-11C]-butyryl-2palmitoyl-rac-glycerol in myocardial infarction in the rat. Eur I Nucl Med Mol Imaging 2002, 29:1516-1522.

105. Otani H, Kagaya Y, Imahori Y, Yasuda S, Fujii R, Chida M, Namiuchi S, Takeda M, Sakuma M, Watanabe J, Ido T, Nonogi H, Shirato K: Myocardial 11C-diacylglycerol accumulation and left ventricular remodelling in patients after myocardial infarction. J Nucl Med 2005, 46:553-559.

106. Chida M, Kagaya Y, Nagata S, Mukoyoshi M, Namiuchi S, Yamane Y, Ishide N, Watanabe J, Takahashi T, Ido T, Shirato K: [18F] labelled diacylglycerol analogue as a potential agent to trace myocardial phosphoinositide metabolism. Nucl Med Biol 2001, 28:815-819.

107. Ogihara-Umeda I, Kojima S: Increased delivery of gallium-67 to tumors using serum-stable liposomes. J Nucl Med 1988, 29:516-523.

108. Kostenikov NA, Fadeev NP, Serzhanina VA, Koresakova LN, Rozenberg OA: [An experimental study of the tumor affinity of gallium-67-labelled sphyngomyelin liposomes]. Vopr Onkol 1992, 38:1080-1084, Russian.

doi:10.1186/2191-219X-1-17

Cite this article as: Belhocine and Prato: Transbilayer phospholipids molecular imaging. EJNMMI Research 2011 1:17.

\section{Submit your manuscript to a SpringerOpen ${ }^{\circ}$ journal and benefit from:}

- Convenient online submission

- Rigorous peer review

- Immediate publication on acceptance

- Open access: articles freely available online

- High visibility within the field

- Retaining the copyright to your article

Submit your next manuscript at $\gg$ springeropen.com 